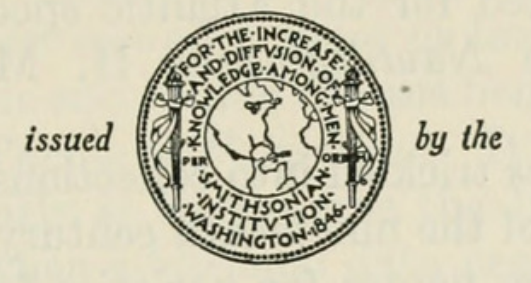

SMITHSONIAN INSTITUTION

U. S. NATIONAL MUSEUM

\title{
THE OCEANIC CRABS OF THE GENERA PLANES AND PACHYGRAPSUS
}

By Fenner A. Chace, Jr.

ON September 17,1492 , at latitude approximately $28^{\circ} \mathrm{N}$. and longitude $37^{\circ} \mathrm{W}$., Columbus and his crew, during their first voyage to the New World, "saw much more weed appearing, like herbs from rivers, in which they found a live crab, which the Admiral kept. He says that these crabs are certain signs of land . . " (Markham, 1893, p. 25). This is possibly the first recorded reference to oceanic crabs. Whether it refers to Planes or to the larger swimming crab, Portunus (Portunus) sayi (Gibbes), which is seldom found this far to the east, may be open to question, but the smaller and commoner Planes is frequently called Columbus's crab after this item in the discoverer's diary.

Although these crabs must have been a source of wonder to mariners on the high seas in the past as they are today, the first adequate description of them did not appear until more than two centuries after Columbus's voyage when Sloane (1725, p. 270, pl. 245, fig. 1) recorded specimens from seaweed north of Jamaica. A short time later Linnaeus (1747, p. 137, pl. 1, figs. 1, $a-b$ ) described a similar form, which he had received from a Göteborg druggist and which was reputed to have come from Canton. This specimen, which Linnaeus named Cancer cantonensis, may be the first record of the Pacific Planes cyaneus. The Atlantic species, found "in Palgi Fuco natante," was finally described under the name Cancer minutus by Linnaeus in the tenth edition of "Systema Naturae" (1758, p. 625). Bowdich (1825, p. 15 , pl. 12 , figs. $2, a-b)$ briefly described and figured a crab found on a floating log northeast of Madeira as Planes clypeatus. 
There is little doubt that Bowdich's species is conspecific with that described earlier by Linnaeus, and the combination Planes minutus is now generally accepted for the Atlantic species, despite repeated attempts to substitute Nautilograpsus H. Milne-Edwards (1837, p. 90) for Planes.

As specimens of Planes trickled into collections from all parts of the world in the early part of the nineteenth century, there was a natural tendency to propose new names for varieties from widely separated localities. A dozen different specific names were applied to these crabs between 1775 and 1858. Thereafter the acquisition of larger series of specimens served to illustrate the variability of these forms. All the post-Linnaean names were subsequently synonymized with $P$. minutus, and no additional ones were proposed except Planes marinus Rathbun (1914, p. 120). The validity of even that species became more and more questionable as time passed without additional specimens being found.

It was the rediscovery of that form that led to the present study. In December 1947 four crabs were found among marine organisms attached to a derelict Japanese mine that drifted ashore at Lincoln Beach, Oreg. These proved to be the species described by Dr. Rathbun and not reliably reported since her record of the type series taken in the Pacific Ocean west of Baja California. Search of the uncataloged collections in the U. S. National Museum revealed two more specimens of this species, these from the Hawaiian Islands. A subsequent query addressed to Dr. C. H. Edmondson at the Bernice P. Bishop Museum in Honolulu led to the discovery of several lots in that institution. A comparison of this form with specimens of Planes minutus indicates that the two are generically as well as specifically distinct and that there are at least two species of Planes s. s., one found in the Atlantic and one in the Pacific.

No attempt is made here to delimit these oceanic forms completely either taxonomically or geographically. Additional material from critical areas and "hosts" must be studied before this can be done. It has been my aim to bring together as many of the scattered references to these species as possible in the hope that workers elsewhere may be encouraged to re-examine material at their disposal or to collect specimens from other areas with a view to verifying or modifying the conclusions outlined here. A species believed to be identical and common in all the warmer seas of the world soon loses its interest; collectors fail to take the trouble to preserve specimens when they are found, and museum workers neglect to examine critically those that are received. If this trend can be reversed as far as these crabs are concerned, it is not unlikely that interesting findings related to speciation and zoogeography may be forthcoming. 
Practically none of the references to Planes in the literature are determinable to species except on a geographic basis. The synonymies listed below have been compiled more or less arbitrarily, all the records from the Atlantic and Indian Oceans being credited to P. minutus and those from the Pacific to $P$. cyaneus. It is very possible that this disposition, particularly as it concerns the Indian Ocean forms, may have to be altered when additional data are obtained.

This opportunity is taken to thank those persons whose gracious assistance has made this study possible: Dr. Louis W. Hutchins, of the Woods Hole Oceanographic Institution, for furnishing the specimens of Pachygrapsus marinus which prompted the survey; John C. Armstrong, of the American Museum of Natural History, Dr. Elisabeth Deichmann, of the Museum of Comparative Zoology, and Dr. C. H. Edmondson, of the Bernice P. Bishop Museum, for providing loans of critical specimens; Mr. and Mrs. Boonyong Nikrodhananda, of Bangkok, Siam, for making a cursory survey of drifting objects that might harbor crabs, during an extended transpacific voyage; and finally my colleagues in the U. S. National Museum for their assistance and encouragement during the preparation of this paper.

\section{MORPHOLOGICAL CHARACTERS}

The species of Planes are extremely variable. This fact has led to the general abandonment of all previous attempts to recognize more than one species in the genus. When Stimpson (1860, p. 231) made the statement that "we are unable to distinguish the specimens [from Baja California] from those collected from Gulfweed in the North Atlantic," the conspecific status of the various forms of Planes seemed to be finally established, and few subsequent attempts to delimit other than the genotype were attempted; even the validity of the very distinct form described as Planes marinus by Dr. Rathbun has been questioned.

The present study indicates, however, that at least some of the variable characters involved show a discontinuity between the Atlantic and Pacific forms of the genus (table 1). Probably the most useful of these characters is based on the relative lengths of the walking legs. In $P$. cyaneus from the Pacific the legs are noticeably shorter than in P. minutus from the Atlantic and Indian Oceans. This difference in relative leg length is not so apparent in figure 1 as it would be if specimens of $P$. minutus and $P$. cyaneus of similar carapace lengths had been available for figuring. The discrepancy is more obvious in figure $2, d, e$, where legs from specimens of similar size are compared. It was found that the simplest way to demonstrate this difference is to compare the combined lengths of the three distal segments of the second walking leg with the carapace length (figs. 6, 7). The slight overlap in this character between the Atlantic and Pacific forms may 
be a real one, or it may be a result of contraction or expansion of the leg in preservative or of the possibility that regenerating and not fully developed legs of $P$. minutus have been included among the material measured.

TABLE 1.-Synopsis of characters

\begin{tabular}{|c|c|c|c|}
\hline Characters & Planes minutus & Planes cyaneus & Pachygrapsus marinus \\
\hline \multicolumn{4}{|l|}{ CARAPACE: } \\
\hline Length.. & 3.7 to $19 \mathrm{~mm}$ & 5 to $25 \mathrm{~mm}$ & 5 to $19 \mathrm{~mm}$. \\
\hline Proportions (see fig. 4) & $\begin{array}{l}\text { About as wide as long, } \\
\text { length to width as } \\
1: 0.91 \text { to } 1.12 \text {. }\end{array}$ & $\begin{array}{l}\text { Usually slightly longer } \\
\text { than wide, length to } \\
\text { width as } 1: 0.86 \text { to } 1.06 \text {. }\end{array}$ & $\begin{array}{l}\text { Distinctly wider than } \\
\text { long, length to width } \\
\text { as } 1: 1.07 \text { to } 1.16 \text {. }\end{array}$ \\
\hline Shape (see fig. 3) & $\begin{array}{l}\text { Subquadrate in young } \\
(3.7-6 \mathrm{~mm} .) \text {; trap- } \\
\text { ezoidal in medium } \\
\text { sized }(6-12 \mathrm{~mm} .) \text {; lat- } \\
\text { erally convex in old } \\
\text { specimens }(12-19 \mathrm{~mm} .) \text {. }\end{array}$ & $\begin{array}{l}\text { Laterally convex at all } \\
\text { ages. }\end{array}$ & $\begin{array}{l}\text { Subquadrate at all } \\
\text { ages. }\end{array}$ \\
\hline $\begin{array}{l}\text { Surface of branchial } \\
\text { regions. }\end{array}$ & Faintly striate laterally.- & Faintly striate laterally...-. & $\begin{array}{l}\text { Distinctly striate lat- } \\
\text { erally. }\end{array}$ \\
\hline MALE ABDOMEN: & & & \\
\hline Shape (see fig. $2, g-i$ ).. & $\begin{array}{c}\text { Rather broadly tri- } \\
\text { angular, length of four } \\
\text { distal segments about } \\
1.24 \text { times basal width } \\
\text { of fourth segment. }\end{array}$ & $\begin{array}{l}\text { Narrowed beyond third } \\
\text { segment, length of four } \\
\text { distal segments about } \\
1.26 \text { times basal width of } \\
\text { fourth segment. }\end{array}$ & $\begin{array}{l}\text { Broadly triangular, } \\
\text { length of } 4 \text { distal seg- } \\
\text { ments about } 1.08 \\
\text { times basal width of } \\
\text { fourth segment. }\end{array}$ \\
\hline Terminal segment.... & $\begin{array}{l}\text { Rather narrowly tri- } \\
\text { angular, about as long } \\
\text { as basal width. }\end{array}$ & $\begin{array}{r}\text { Laterally convex, about } \\
0.9 \text { as long as basal width. }\end{array}$ & $\begin{array}{l}\text { Broadly triangular, } \\
\text { about } 0.9 \text { as long as } \\
\text { basal width. }\end{array}$ \\
\hline Chelae: & & & \\
\hline $\begin{array}{l}\text { Fixed finger (see fig. } \\
2, a-c) \text {. }\end{array}$ & $\begin{array}{c}\text { Bent sharply downward, } \\
\text { especially in males. }\end{array}$ & $\begin{array}{l}\text { Bent sharply downward, } \\
\text { especially in males. }\end{array}$ & $\begin{array}{l}\text { Not noticeably bent } \\
\text { downward. }\end{array}$ \\
\hline Surface of hand & $\begin{array}{l}\text { With prominent sharp } \\
\text { granules near lower } \\
\text { margin. }\end{array}$ & $\begin{array}{l}\text { With prominent sharp } \\
\text { granules near lower mar- } \\
\text { gin. }\end{array}$ & $\begin{array}{l}\text { Few inconspicuous } \\
\text { granules near lower } \\
\text { margin. }\end{array}$ \\
\hline $\begin{array}{l}\text { WALKING LEGS: } \\
\text { Form (see fig. } 2, d-f \text { ).- }\end{array}$ & $\begin{array}{l}\text { Long, slender, and } \\
\text { flattened. }\end{array}$ & $\begin{array}{l}\text { Short, slender, and flat- } \\
\text { tened. }\end{array}$ & $\begin{array}{l}\text { Rather short, stout, } \\
\text { and not noticeably } \\
\text { flattened. }\end{array}$ \\
\hline $\begin{array}{l}\text { Hairs on upper an- } \\
\text { terior margin of } \\
\text { propodus of three } \\
\text { anterior pairs. }\end{array}$ & $\begin{array}{l}\text { Forming a natatory } \\
\text { fringe. }\end{array}$ & Forming a natatory fringe_. & $\begin{array}{l}\text { Stout and forming a } \\
\text { dense growth with- } \\
\text { out a natatory fringe. }\end{array}$ \\
\hline $\begin{array}{l}\text { Proportion of length } \\
\text { of three distal seg- } \\
\text { ments of second pair } \\
\text { to carapace length } \\
\text { (see fig. 6). }\end{array}$ & 0.83 to 1.07 & 0.68 to 0.89 & 0.77 to 0.99 . \\
\hline
\end{tabular}

Planes cyaneus appears to be a somewhat larger form than $P$. minutus. The smallest specimens of the latter examined measure 3.7 $\mathrm{mm}$. in carapace length, and the largest $19 \mathrm{~mm}$. Comparable measurements for $P$. cyaneus are 5 and $25 \mathrm{~mm}$. The mean carapace width is usually about the same as the mean length in $P$. minutus, whereas it is somewhat less in P. cyaneus (figs. 4,5 ); this character is demonstrable only in long series of specimens, however, and is of far less importance than the length of the walking legs. 


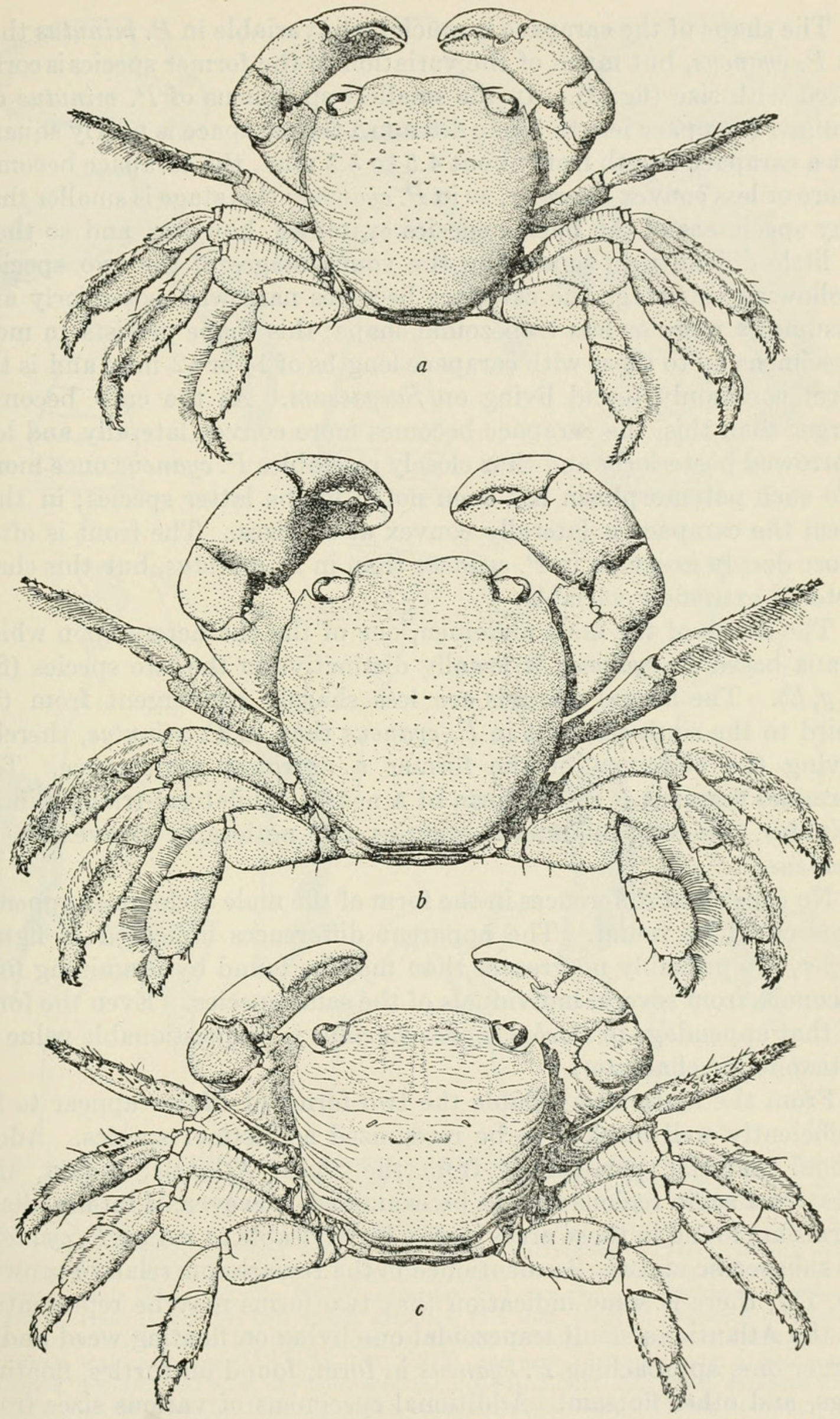

Figure 1.-a, Planes minutus, male (U. S. N. M. No. 4558), carapace $13.4 \mathrm{~mm}$. long b, Planes cyaneus, male (U.S.N.M. No. 20695), carapace $16.6 \mathrm{~mm}$. long; c. Pachygrapsus marimus, male paratype (U.S.N.M. No. 22833), carapace $13.8 \mathrm{~mm}$. long. 
The shape of the carapace is much more variable in $P$. minutus than in $P$. cyaneus, but much of the variation in the former species is correlated with size (fig. 3 ). In the smallest specimens of $P$. minutus examined (carapace length 3.8 to $4.5 \mathrm{~mm}$.) the carapace is nearly square. At a carapace length from about 4.5 to $5.5 \mathrm{~mm}$., the carapace becomes more or less convex laterally, as in P.cyaneus; this stage is smaller than any specimens of the Pacific species examined, however, and so there is little difficulty in separating the young stages of the two species. Following this stage the carapace becomes narrowed posteriorly and assumes a more or less trapezoidal shape; this shape persists in most specimens up to those with carapace lengths of 11 or $12 \mathrm{~mm}$. and is the form commonly found living on Sargassum. As the crab becomes larger than this, the carapace becomes more convex laterally and less narrowed posteriorly and thus closely resembles $P$. cyaneus once more. No such polymorphism has been noted in the latter species; in that form the carapace is laterally convex at all sizes. The front is often more deeply excavate in $P$. cyaneus than in $P$. minutus, but this character is extremely variable.

The shape of the male abdomen, one of the characters upon which Dana based $P$. cyaneus, is usually distinctive in the two species (fig. $2, g, h)$. The lateral margins are less sharply convergent from the third to the sixth segment in $P$. cyaneus than in $P$. minutus, thereby giving the abdomen of the former a narrower appearance. The terminal segment is in the form of a nearly equilateral triangle in $P$. minutus, whereas its lateral margins are noticeably convex in $P$. cyaneus.

No consistent differences in the form of the male abdominal appendages could be found. The apparent differences indicated in figure $2, j-r$, are probably no greater than may be found by examining first pleopods from several individuals of the same species. Even the form of that appendage in Pachygrapsus marinus is of questionable value as a taxonomic character.

From the material available the two forms of Planes appear to be sufficiently well marked to be recognized as distinct species. Additional material, particularly from the South Atlantic, Indian, and western Pacific regions should be examined, however; if intermediate forms are found in those areas it may be advisable to reduce $P$. cyaneus to subspecific status. As mentioned in the remarks on relative growth (p. 73), there is some indication that two forms may be represented in the Atlantic: a small trapezoidal one living on floating weed and a larger one, approaching $P$. cyaneus in form, found on turtles, floating logs, and other flotsam. Additional specimens of various sizes from the latter habitat should be examined to determine whether this form is distinct or not. 


$$
\begin{aligned}
& C \bigcirc Q^{\prime \prime} \\
& \text { 異 } \mathrm{A} \text {, } \\
& { }_{1}
\end{aligned}
$$


The species that Dr. Rathbun (1914, p. 120, pl. 3) described as Planes marinus differs so markedly from the other species of Planes in its wider, subquadrate, and distinctly striate carapace, differently formed chelae, and the absence of a natatory fringe of hairs on the propodi of the first three pairs of walking legs (table 1) that it is here transferred to the genus Pachygrapsus. Except for its much smaller size, this species is very similar to Pachygrapsus crassipes Randall from the Pacific coast of North America and the shores of the Japanese islands and Korea. The only obvious character, apart from size, in which $P$. crassipes and $P$. marinus differ is the absence of lateral lobules on the front in the latter species. Unless this species is removed from Planes on the basis of the characters mentioned above, the distinction between Planes and Pachygrapsus would cease to exist and Pachygrapsus would have to be synonymized with Planes.

Examination of one of the two specimens recorded as Planes marinus by Ward $(1939$, p. 14) indicates that these specimens, like the others mentioned in that paper, are P. cyaneus.

\section{RELATIVE GROWTH}

The examination and measurement of the large number of specimens of Planes minutus used in this study suggest a problem involving the relative growth of that species which might prove to be of considerable interest if it could be followed up with the analysis of more material from drift logs, turtles, and so forth.

The carapace length-width relationship remains fairly constant, with a slight tendency toward narrowing, from the smallest immature specimens examined to a carapace length of about $11 \mathrm{~mm}$. At this stage the carapace seems to become somewhat narrower rather abruptly and continues to become narrower at a slightly more rapid rate than during the younger stages (figs. 4, 5). A similar, but even more striking, trend is noticed in the relative shortening of the walking legs (figs. 6, 7). In other words, there is a tendency for the larger specimens of $P$. minutus to approach the laterally convex, narrow form (fig. 3 ) and short walking legs of P.cyaneus. These similarities are so striking that I was at first led toward the belief that the larger Atlantic specimens are conspecific with those from the Pacific. It will be seen from figures 4 through 7 , however, that the mean width of the carapace in the Atlantic form never becomes quite as narrow relative to the length as in the Pacific form, and the legs are always distinctly longer in the Atlantic species (tables 2, 3).

Although the material at hand has not been sufficiently well documented to verify the hypothesis, it is not improbable that most of the specimens of $P$. minutus having a carapace length of more than about $11 \mathrm{~mm}$. are not found on Sargassum, but on flotsam and turtles. The 
TABLE 2.-Mean values of carapace proportions

\begin{tabular}{|c|c|c|c|c|c|c|c|c|}
\hline \multicolumn{3}{|c|}{ Planes minutus } & \multicolumn{3}{|c|}{ Planes cyaneus } & \multicolumn{3}{|c|}{ Pachygrapsus marinus } \\
\hline $\begin{array}{l}\text { Number } \\
\text { of speci- } \\
\text { mens }\end{array}$ & $\begin{array}{l}\text { Mean } \\
\text { carapace } \\
\text { length }\end{array}$ & $\begin{array}{l}\text { Mean } \\
\text { carapace } \\
\text { width }\end{array}$ & $\begin{array}{l}\text { Number } \\
\text { of speci- } \\
\text { mens }\end{array}$ & $\begin{array}{l}\text { Mean } \\
\text { carapace } \\
\text { length }\end{array}$ & $\begin{array}{l}\text { Mean } \\
\text { carapace } \\
\text { width }\end{array}$ & $\begin{array}{l}\text { Number } \\
\text { of speci- } \\
\text { mens }\end{array}$ & $\begin{array}{l}\text { Mean } \\
\text { carapace } \\
\text { length }\end{array}$ & $\begin{array}{l}\text { Mean } \\
\text { carapace } \\
\text { width }\end{array}$ \\
\hline$\because$ & $\begin{array}{l}\text { Milli- } \\
\text { meters }\end{array}$ & $\begin{array}{l}\text { Milli- } \\
\text { meters }\end{array}$ & & $\begin{array}{l}\text { Milli- } \\
\text { meters }\end{array}$ & $\begin{array}{l}\text { Milli- } \\
\text { meters }\end{array}$ & & $\begin{array}{l}\text { Milli- } \\
\text { meters }\end{array}$ & $\begin{array}{l}\text { Milli- } \\
\text { meters }\end{array}$ \\
\hline 57 & 4. 2 & 4. 2 & $-\cdots$ & $\ldots-$ & $\cdots-$ & ---- & $-\cdots$ & $-\cdots$ \\
\hline 89 & 5.0 & 5.1 & $-\ldots$ & $-\cdots$ & $-\cdots$ & - & --.-- & --.-- \\
\hline 78 & 6.0 & 6.2 & 15 & 6.2 & 6.0 & $-\cdots-$ & ---- & -.--- \\
\hline 76 & 7.0 & 7.3 & $-\ldots$ & $-\cdots$ & ----- & 6 & 6.9 & 7.7 \\
\hline 76 & 8.0 & 8.3 & 8 & 8.3 & 8.3 & $-\ldots$ & --_-- & - \\
\hline 53 & 9.0 & 9.4 & - - - - & $-\cdots$ & $-\cdots$ & 8 & 8.7 & 9.8 \\
\hline 46 & 10.0 & 10.4 & --.-- & - - - & -..-- & -...- & -..-- & $-\ldots$ \\
\hline 22 & 10.9 & 11.2 & $-\cdots-$ & - - - & - - - & -...-. & -...-- & -.--- \\
\hline 9 & 12.4 & 12.7 & 11 & 11.8 & 11. 6 & 6 & 12.3 & 13.9 \\
\hline 10 & 14. 3 & 14. 7 & 12 & 14. 1 & 14. 2 & 16 & 14.0 & 15.8 \\
\hline$-\cdots$ & - & - - & - & - & - & 7 & 15.5 & 17.4 \\
\hline 9 & 17.0 & 17.3 & 10 & 17.3 & 17. 2 & 5 & 17.6 & 19.9 \\
\hline -...... & -...... & -....... & 2 & 22.6 & 22.5 & --.-- & --.-- & - \\
\hline
\end{tabular}

TABLE 3.-Mean values of total length of three distal segments of second walking leg

\begin{tabular}{|c|c|c|c|c|c|c|c|c|}
\hline \multicolumn{3}{|c|}{ Planes minutus } & \multicolumn{3}{|c|}{ Planes cyaneus } & \multicolumn{3}{|c|}{ Pachygrapsus marinus } \\
\hline $\begin{array}{l}\text { Number } \\
\text { of speci- } \\
\text { mens }\end{array}$ & $\begin{array}{l}\text { Mean } \\
\text { carapace } \\
\text { length }\end{array}$ & $\begin{array}{c}\text { Mean } \\
\text { length } \\
\text { of leg } \\
\text { segments }\end{array}$ & $\begin{array}{l}\text { Number } \\
\text { of speci- } \\
\text { mens }\end{array}$ & $\begin{array}{l}\text { Mean } \\
\text { carapace } \\
\text { length }\end{array}$ & $\begin{array}{c}\text { Mean } \\
\text { length } \\
\text { of leg } \\
\text { segments }\end{array}$ & $\begin{array}{l}\text { Number } \\
\text { of speci- } \\
\text { mens }\end{array}$ & $\begin{array}{l}\text { Mean } \\
\text { carapace } \\
\text { length }\end{array}$ & $\begin{array}{c}\text { Mean } \\
\text { length } \\
\text { of leg } \\
\text { segments }\end{array}$ \\
\hline & $\begin{array}{l}\text { Milli- } \\
\text { meters }\end{array}$ & $\begin{array}{l}\text { Milli- } \\
\text { meters }\end{array}$ & & $\begin{array}{l}\text { Milli- } \\
\text { meters }\end{array}$ & $\begin{array}{l}\text { Milli- } \\
\text { meters }\end{array}$ & & $\begin{array}{l}\text { Milli- } \\
\text { meters }\end{array}$ & $\begin{array}{l}\text { Milli- } \\
\text { meters }\end{array}$ \\
\hline 16 & 4.2 & 4.1 & $\cdots$ & -ne- & - n- & - & $-\ldots$ & - \\
\hline 46 & 5.0 & 5. 0 & -n- & $-\cdots$ & $\cdots$ & -..-- & $-\cdots$ & $-\ldots$ \\
\hline 46 & 6.0 & 6. 0 & 15 & 6.3 & 5.1 & $-\cdots$ & $\cdots-$ & $-\cdots$ \\
\hline 52 & 7.0 & 7.0 & $-\cdots$ & $-\cdots$ & $\ldots$ & 4 & 7.3 & 6.8 \\
\hline 54 & 7.9 & 7.8 & 8 & 8.2 & 6.6 & 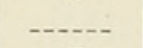 & $\cdots-$ & $\ldots$ \\
\hline 45 & 8.9 & 8.7 & - n & - - - & $\ldots-$ & 7 & 8.7 & 7.8 \\
\hline 41 & 9.9 & 9.6 & - - & $-\cdots$ & - - & - - - & $-\cdots$ & $-\ldots$ \\
\hline 21 & 10.9 & 10.3 & 12 & 11.6 & 9.0 & $-\cdots$ & - - - & $-\cdots$ \\
\hline 15 & 12.6 & 11. 6 & $\ldots$ & -..- & - - - & 6 & 12.3 & 10.4 \\
\hline 12 & 14. 5 & 13.0 & 12 & 14.1 & 10.5 & 16 & 14.0 & 11.8 \\
\hline 12 & 16.3 & 14.4 & - & - & - & 7 & 15.5 & 12.8 \\
\hline 4 & 18.3 & 16.0 & 10 & 17.0 & 13.1 & 5 & 17.6 & 14. 2 \\
\hline-1 & - & --- & 5 & 22.5 & 16. 9 & - & - & -...... \\
\hline
\end{tabular}

shorter legs may be better adapted to this more sessile existence or, conversely, the longer legs of the smaller individuals may be advantageous in scurrying and swimming about among the floating weed. Whether there is a gradual reduction in the relative lengths of the legs with the transfer of the animal to a different means of transport or whether there are two forms of Planes in the North Atlantic - a small, trapezoidal form that spends its entire life on floating weed and a larger, laterally convex, and short-legged form that lives only on flotsam and turtles-can be determined only when more material, 874803-51-2 
particularly of immature specimens, from flotsam and turtles is available for study.

Similar trends are not apparent in the specimens of Planes cyaneus or Pachygrapsus marinus, but the relative growth of these two species cannot be reliably demonstrated from the material studied.
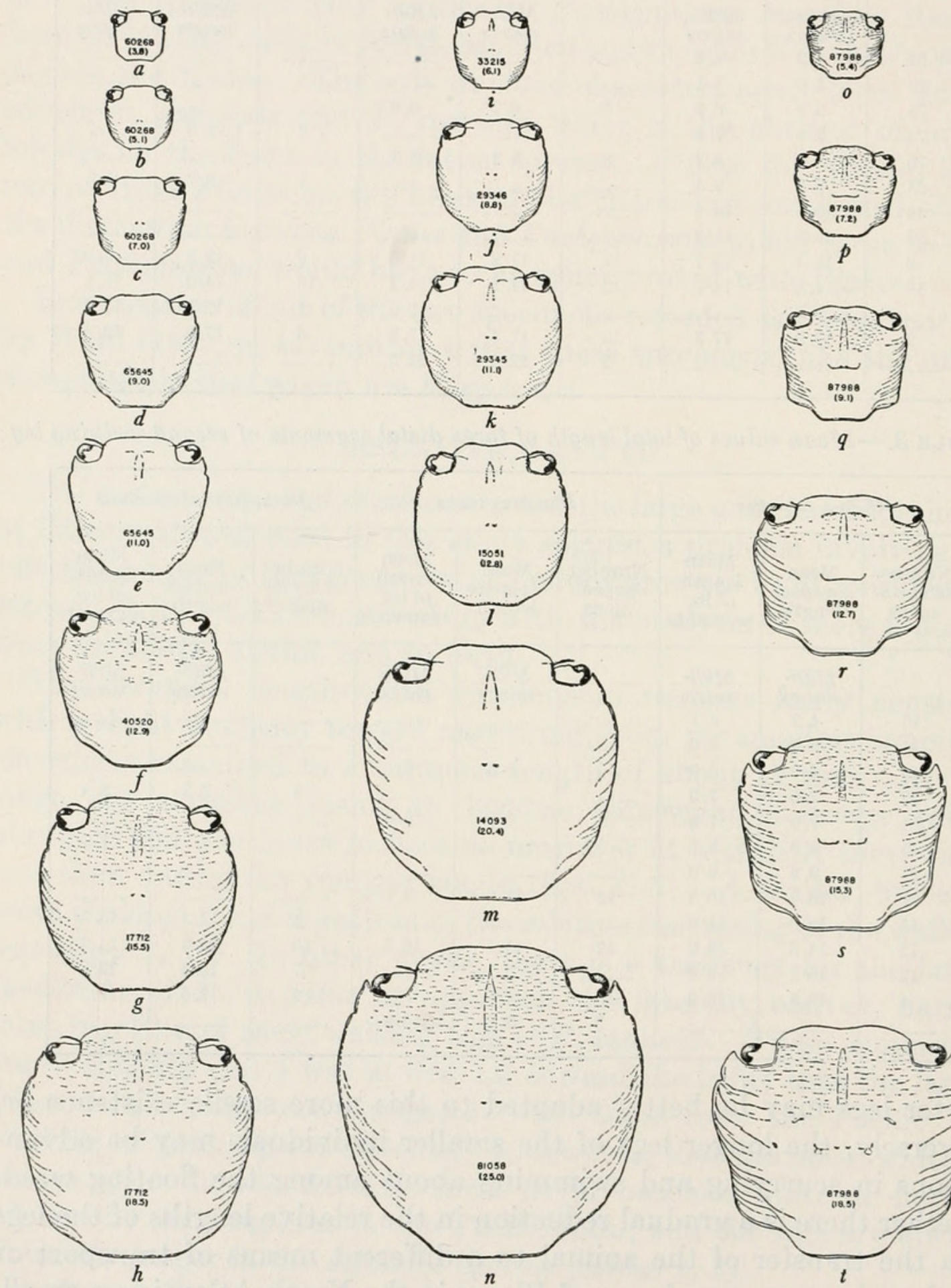

Figure 3.-Carapace growth in males of Planes minutus $(a-h)$, Planes cyaneus $(i-n)$, and Pachygrapsus marinus (o-t). The figures denote the U.S.N.M. catalog numbers and, in parentheses, the carapace lengths in $\mathrm{mm}$. 


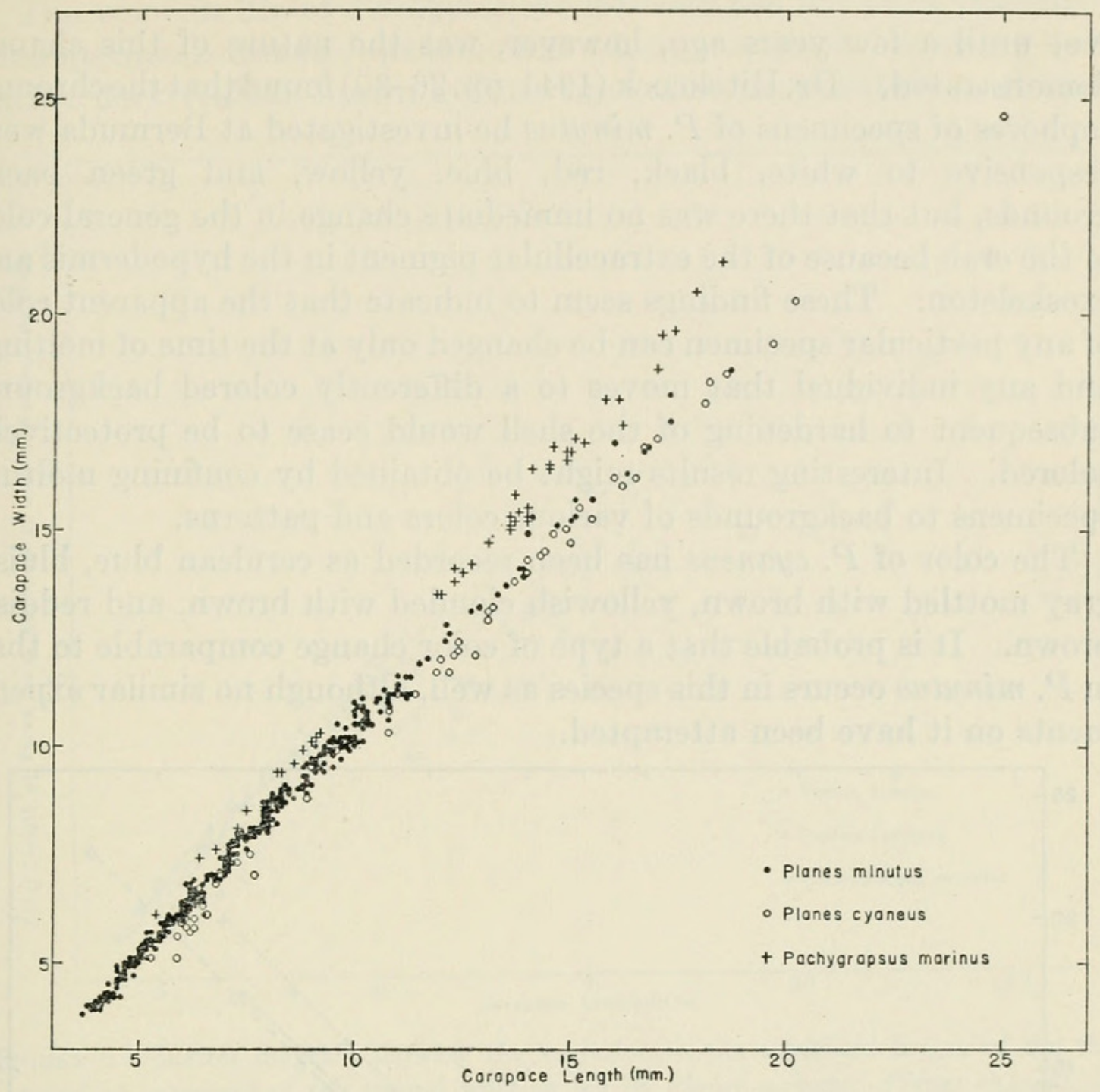

Figure 4.-Scatter diagram showing the variation in proportions of the carapace in Planes minutus, Planes cyaneus, and Pachygrapsus marinus.

\section{COLOR}

The variable and protective coloration of Planes minutus has been a cause of speculation for more than a century. Some of the early workers believed that those specimens which were greenish or brownish yellow mottled with darker shades of the same color sought out Sargassum clumps to live on in order to be less conspicuous to their enemies. These Sargassum inhabitants also often have a large white or yellowish patch on the dorsal surface, which seems to duplicate the patches of bryozoan colonies with which the plant fronds are almost invariably encrusted. Those specimens found on turtles are usually yellowish, those on logs and drifting trees often dark reddish brown, and those on the pelagic gastropod Janthina lilac blue. Light reddish shades have also been recorded on several occasions. Examples of some of these colors are shown in Murray and Hjort (1912, pl. 6).

Müller (1881, p. 473) was apparently the first to suggest that these crabs change their color according to the object to which they cling. 
Not until a few years ago, however, was the nature of this change demonstrated. Dr. Hitchcock (1941,pp. 26-30) found that the chromatophores of specimens of $P$. minutus he investigated at Bermuda were responsive to white, black, red, blue, yellow, and green backgrounds, but that there was no immediate change in the general color of the crab because of the extracellular pigment in the hypodermis and exoskeleton. These findings seem to indicate that the apparent color of any particular specimen can be changed only at the time of molting, and any individual that moves to a differently colored background subsequent to hardening of the shell would cease to be protectively colored. Interesting results might be obtained by confining molting specimens to backgrounds of various colors and patterns.

The color of $P$. cyaneus has been recorded as cerulean blue, bluish gray mottled with brown, yellowish clouded with brown, and reddish brown. It is probable that a type of color change comparable to that in $P$. minutus occurs in this species as well, although no similar experiments on it have been attempted.

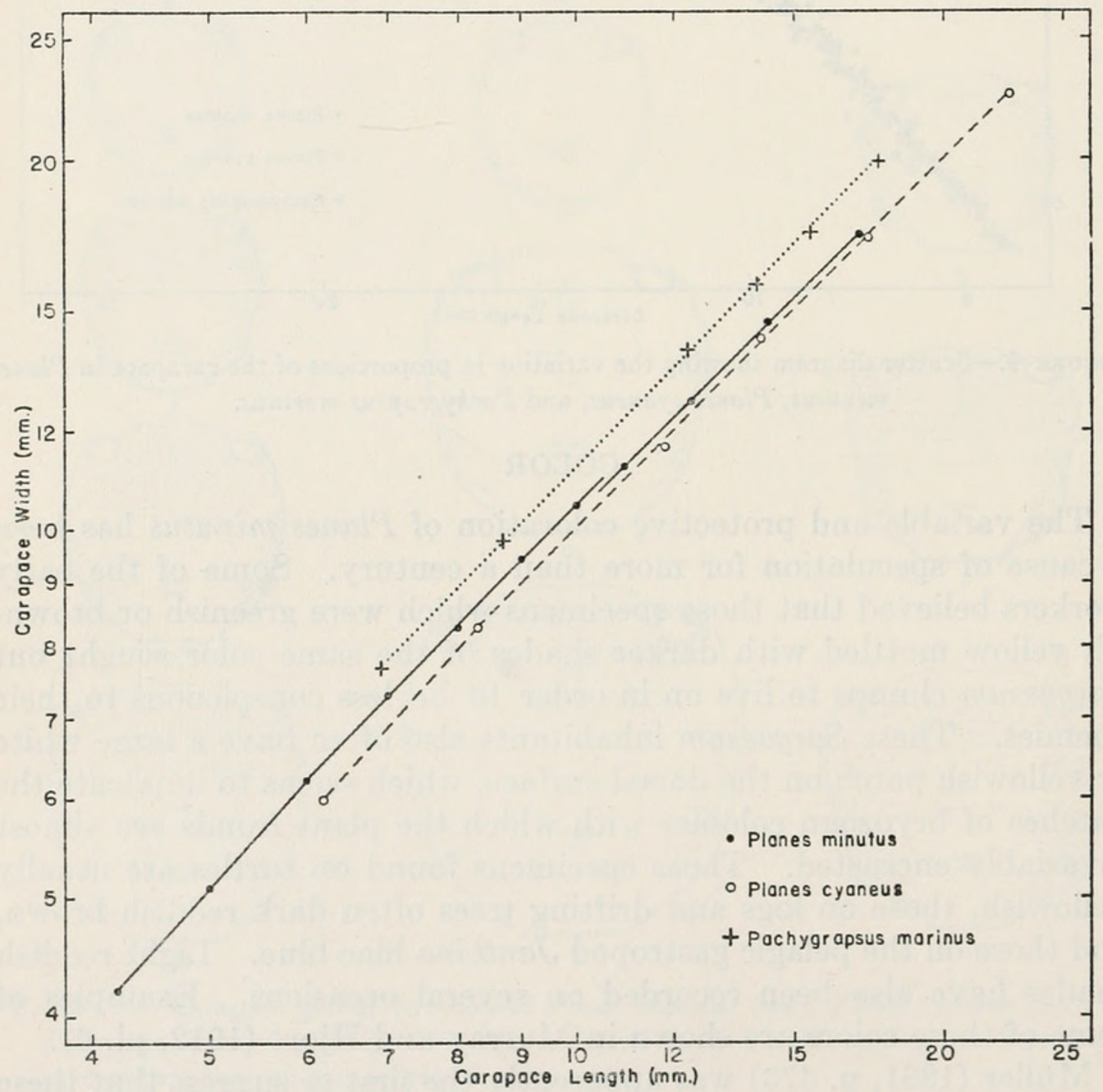

Figure 5.-Relative growth of the carapace in Planes minutus, Planes cyaneus, and Pachygrapsus marinus, based on mean values (table 2 ) plotted logarithmically. 
The color in life of Pachygrapsus marinus has not been published. The specimens from a Japanese mine which prompted this survey were rather dark reddish brown a short time after preservation in alcohol.

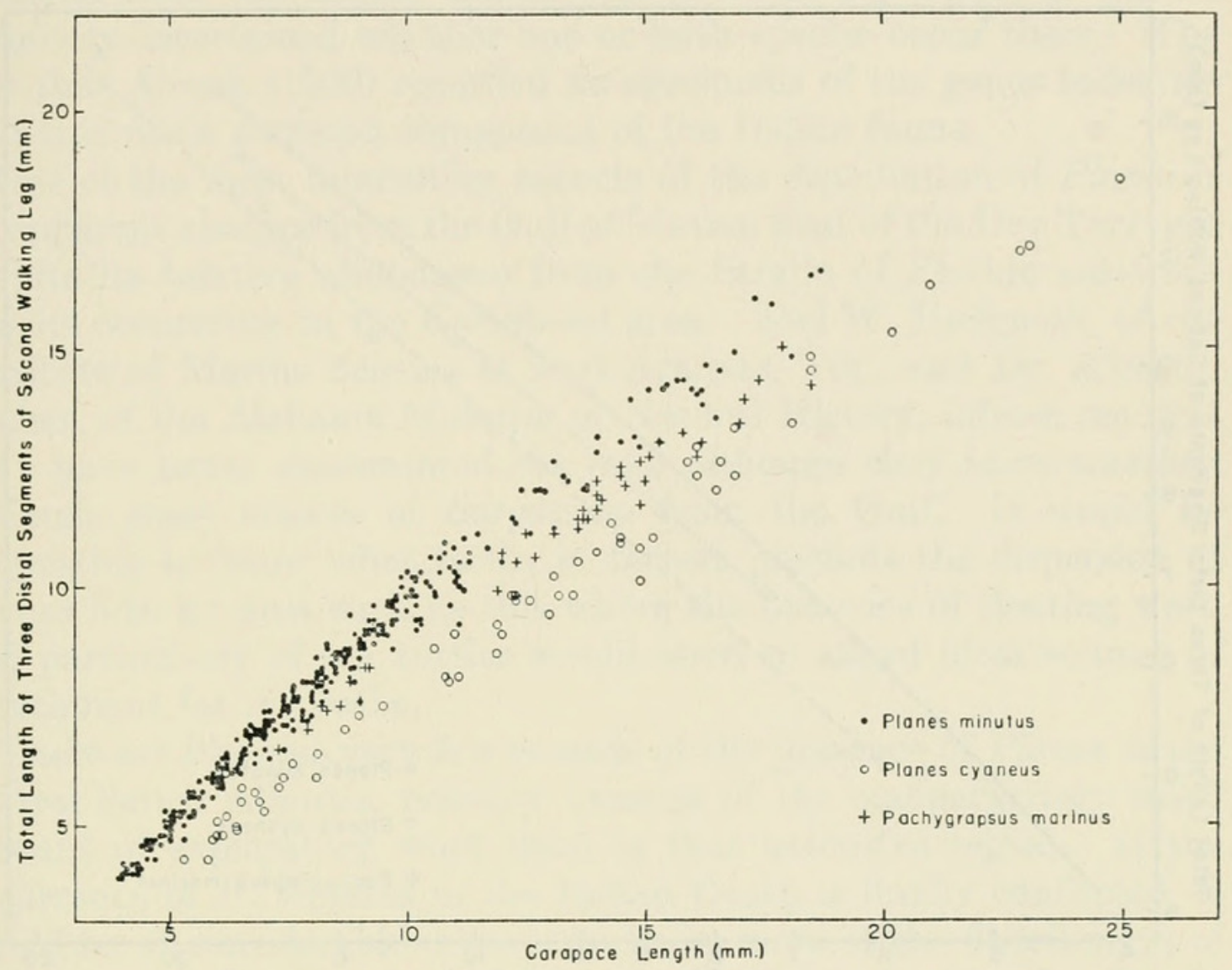

Figure 6.-Scatter diagram showing the variation in the combined length of the three terminal segments of the second walking leg in Planes minutus, Planes cyaneus, and Pachygrapsus marinus.

\section{FOOD}

The only published record of the stomach contents of any of these species is that of Miss Crane (1937, p. 78) based on a large ovigerous female of Planes cyaneus taken from the tail of a green turtle. The stomach of this specimen contained finely digested animal matter. Miss Crane suggests the possibility that this food material might represent the excrement of the turtle. Some support is given to this theory by the fact that larger specimens of Planes are commonly found around the tail and hind legs of turtles. Specimens living on other objects, however, must be able to assimilate less digested food.

\section{DISTRIBUTION}

The relative abundance of these oceanic crabs is more or less dependent upon the prevalence of flotsam or of floating or swimming organisms to which the crabs may cling. They are therefore found far more commonly on Sargassum in the Sargasso Sea area of the North Atlantic than in any other part of the world. Records of their occur- 
rence in other areas are still too scattered and frequently too unreliable to justify the usual distribution note that Planes is "found in all tropical and temperate seas."

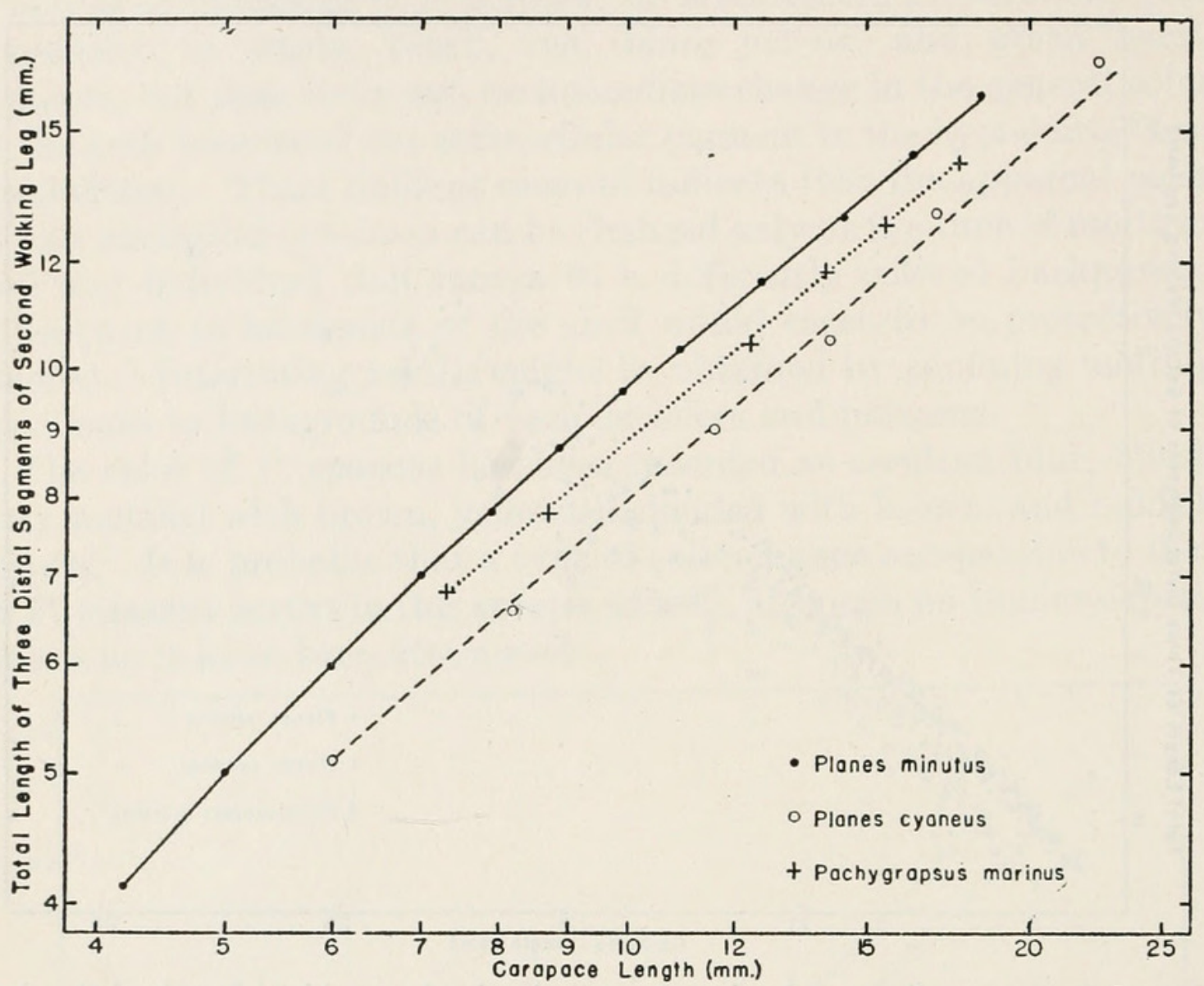

FigURE 7.-Relative growth of the three terminal segments of the second walking leg in Planes minutus, Planes cyaneus, and Pachygrapsus marinus, based on mean values (table 3) plotted logarithmically.

The more reliable locality records for the species of Planes are indicated in figure 8. Not included on this chart are several references in the literature to Australian specimens without specific locality data. Even some of the localities indicated, particularly those from older records, require verification. It is obvious that in some cases specimens picked up at sea have been referred to the last port of call of the vessel involved. The large lot of specimens recorded by Dr. Rathbun (1918, p. 257) from the Galápagos Islands (U.S.N.M. No. 5046) prove to belong to the Atlantic Planes minutus. This determination is substantiated by the fact that the shrimp from the same collection belong to the Sargassum fauna of the North Atlantic. Similar circumstances may explain the record of the single specimen of $P$. cyaneus from Mauritius (U.S.N.M. No. 17667) if the presence of $P$. minutus alone in the Indian Ocean is borne out by other material. Even one of the lots of $P$. minutus from that region, that from Kerguelen Island (U.S.N.M. No. 15054), is questionable; in the collections of 
the U. S. National Museum is a specimen of Portunus (Portunus) sayi (Gibbes) that bears the same locality data, and this crab is otherwise reliably reported only from the Atlantic. Examination of additional material from the Indian Ocean will be necessary before it can be definitely ascertained whether one or both species occur there. The fact that Alcock (1900) recorded no specimens of the genus indicates that it is not a common component of the Indian fauna.

One of the most interesting aspects of the distribution of Planes is its apparent absence from the Gulf of Mexico west of the Dry Tortugas despite its relative abundance from the Straits of Florida eastward and its occurrence in the Caribbean area. Joel W. Hedgpeth, of the Institute of Marine Science at Port Aransas, Tex., and Dr. Allan F. Archer, of the Alabama Museum of Natural History, inform me that they have never encountered the crab although they have searched through great masses of Sargassum from the Gulf. It would be interesting to know what factor or factors preclude the dispersion of Planes into an area such as this where the presence of floating weed and particularly of sea turtles would seem to afford ideal sources of attachment for the crabs.

There are likewise very few records of the presence of Planes in the central South Atlantic, possibly because of the comparatively small amount of exploratory work done in that extensive region. If the occurrence of $P$. minutus in the Indian Ocean is finally confirmed, it would be of considerable interest to know more of the distribution of the genus in the South Atlantic, particularly whether the Pacific $P$. cyaneus extends into the western part of the South Atlantic and, if it does, whether the ranges of the two species overlap there. Inasmuch as Planes is not infrequently found among the under-water growth on ships' hulls and as the crabs are said to be common in the Straits of Magellan (Jacquinot and Lucas, 1853, p. 78), through which much of the steamship traffic passed in the early part of this century, it would be remarkable if intermingling of the two forms had not occurred commonly in the past.

The known distribution of Pachygrapsus marinus is limited to the records from the coast of Oregon and the Hawaiian Islands, in addition to the type locality west of Baja California; further collecting will probably show its range to be far more extensive in the eastern North Pacific and possibly in the western portion as well. Dr. C. H. Edmondson informs me that, of 18 lots and 150 or more specimens identified as Planes minutus in the Bernice P. Bishop Museum, 3 lots containing a total of 22 specimens are apparently Pachygrapsus marinus and 3 of the remaining 15 lots contain both Planes and Pachygrapsus, including 30 or more specimens of the latter. All the lots containing Pachygrapsus marinus were taken off Oahu. 


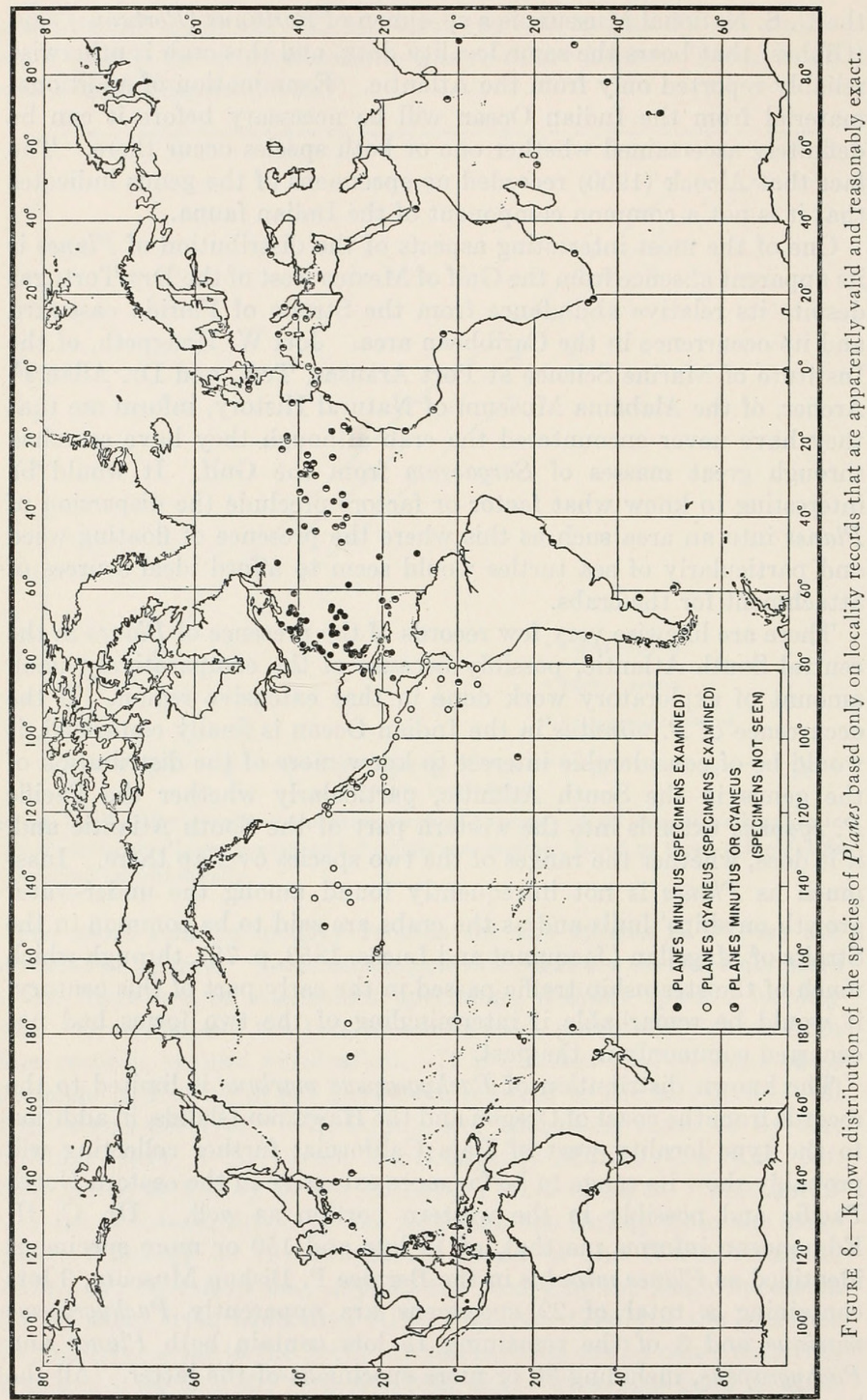




\section{Genus PLANES Bowdich}

PLANES MINUTUS (Linnaeus)

Cancellus marinus minimus quadratus Sloane, 1725, p. 270, fig. 1 ("on the Sargasso and other Submarine Sea-Plants, on the Northside of Jamaica").

Cancer minutus Linnaeus, 1758, p. 625 ("Habitat in Palgi Fuco natante, supra aquam saepius cursitans"); 1767, p. 1040 [2040] (west Europe and "Pelagi Fuco natante").-OsBeck, 1771, p. 116 (Sargasso Sea).-FABricius, 1775, p. 402.-MÜller, O. F., 1776, p. 195.-Pennant, 1777, p. 3, pl. 1, fig. 2 (British shores, among algae).-FABricius, 1781, p. 497.-Herbst, 1783, p. 110, pl. 2, fig. 32.-FABricius, 1787, p. 316.-Olivier, 1791, pp. 143, 154. -FABRicius, 1793, p. 443 ("In Pelago frequens").

Cancer pusillus Fabricius, 1775, p. 402 ("in Oceano boreali").-Herbst, 1783, p. 112.-FABricius, 1787 , p. 316 .-Olivier, 1791 , pp. 143, 155.-Fabricius, 1793 , p. 443.

Turtle-Crab Browne, 1789, p. 421, pl. 42, fig. 1 ("on the back of a turtle, near the western islands").

Pinnotheres glaberimus Bosc, 1801-02, p. 244 ("dans la haute mer sur les fucus"). Not Cancer glaberrimus Herbst, 1790.

Pinnotheres minutus Bosc, 1801-02, p. 244.

Pinnotheres pusillus Bosc, 1801-02, p. 244.

Grapsus minutus Latreille, 1802-03, p. 68.-LeACH, 1814, p. 430.

Grapsus cinereus SAY, 1817, p. 99 (Gulf Stream, common). Not G. cinereus Bosc, 1802.

Grapsus pelagicus SAY, 1818, p. 442.-Roux, 1828, p. 55, pl. 6, figs. 7-9 (off Sardinia, on turtles).--Нгтснсоск, E., 1835, p. 29 (Gulf Stream, on seaweed).Thompson, J. V., 1836, p. 374 (off America, on gulfweed, abundant).Milne-Edwards, H., 1852, p. 174.

Planes clypeatus Bowdich, 1825, p. 15, pl. 12, figs. 2a-b (northeast of Madeira, on water-logged logs of American pine, in great numbers among Lepas anatifera).

Grapsus testudinum Roux, 1828, p. 52, pl. 6, figs. 1-6 (under folds of skin of legs and anus of turtles).

Nautilograpsus minutus Milne-Edwards, H., 1837, p. 90.-Macleay, 1838, p. 66 (Atlantic, on gulfweed).-Krauss, 1843, p. 44 (Gulf Stream).DE KAY, 1844, p. 15 (off New York harbor, on seaweed).-Goodsir, 1845, p. 73 , pl. 7 , fig. 1 (lat. $25^{\circ}$ to $36^{\circ}$ N., long. $40^{\circ}$ W.; lat. $40^{\circ}$ N.).-GibBes, 1850, p. 182 [18].-Milne-Edwards, H., 1852, p. 174.-Stimpson, 1858, p. 103 [49] (North Atlantic, common in Sargassum).-Milne-Edwards, A., 1862, p. F-6 (Réunion Island, Indian Ocean).-Heller, 1863, p. 114 (African coast of Mediterranean; Cyprus; Genoa; Lesina); 1865, p. 50 (Sargasso Sea).--Sмith and Harger, 1874, p. 26 (off Georges Bank; lat. $41^{\circ} 25^{\prime}$ N., long. $65^{\circ} 05-30^{\prime}$ W.).-Brocchi, 1875 , p. 80 , pl. 17 , fig. 133 .MAN, 1879 , p. 69 (part: Atlantic Ocean).-Moseley, 1879, p. 568 (Sargasso Sea, on Sargassum).-Sмiтн, 1879 , p. 120 (Bermuda; lat. $41^{\circ} 20-30^{\prime}$ N., long. $65^{\circ}$ to $65^{\circ} 30^{\prime}$ W.) ; 1880 , p. 263 (Woods Hole, Mass.).-Sтоssich, 1880 , p. 192 (Lesina).-WAGNeR, 1880, p. 96.-KINGSLEY, 1881, p. 202 (part: Gulf Stream; West Indies; Surinam; Falkland Islands [?]; Natal; Rio Gambia; France).-Czerniavsky, 1884, p. 135 (Odessa).-Milne-Edwards, A., 1884, p. 25 (Sargasso Sea, on Sargassum).-CARus, 1885, p. 524.-Verrill, 1885 , p. 591 (Gulf Stream, common, usually clinging to clusters of floating seaweeds).-Miers, 1886, p. 254 (part: Gomera, Canary Islands; between Bermuda and Azores; off Sombrero Island, West Indies; northwest Atlantic, 874803-51-3 
on gulfweed; North Atlantic, on Fucus).-Pouchet and Guenne, 1886, p. 878 (Azores, from stomach of turtle, Thalassochelys caretta).-- -мітн, 1886, p. 618.-Barrors, 1888, p. 15 (Ponta-Delgada, Sao Miguel, Azores, on timber).-Gourret, 1888, p. 10 (Marseilles, on ships from the Atlantic and the Indies).-Heilprin, 1888, p. 320 (off Shelly Bay, Bermudas).Chevreux and Guerne, 1893 , pp. 443-444 (lat. $37^{\circ} 55^{\prime}$ N., long. $0^{\circ} 40^{\prime}$ E., clinging to tail of turtle, Thalassochelys caretta; lat. $37^{\circ} 26^{\prime}$ N., long. $0^{\circ} 50^{\prime}$ E., clinging to tail of Thalassochelys).-OrtmanN, 1893, p. 58 (Florida Stream, on Sargassum; Sargasso Sea, on Sargassum; South Equatorial Current).Milne-Edwards, A., and Bouvier, 1894 , p. 49 (lat. $39^{\circ} 08^{\prime}$ N., long. $28^{\circ} 34^{\prime}$ W., on floating barrel; lat. $42^{\circ} 21^{\prime} 29^{\prime \prime}$ N., long. $18^{\circ} 33^{\prime} 45^{\prime \prime}$ W.; lat. $42^{\circ} 31^{\prime} 21^{\prime \prime}$ N., long. $19^{\circ} 38^{\prime} 08^{\prime \prime}$ W.; lat. $43^{\circ} 29^{\prime} 30^{\prime \prime}$ N., long. $21^{\circ} 33^{\prime} 40^{\prime \prime}$ W., on flotsam; Fayal, Horta, Azores, on rocks at low tide; lat. $42^{\circ} 02^{\prime} 26^{\prime \prime}$ N., long. $44^{\circ} 05^{\prime} 30^{\prime \prime}$ W., on Sargassum; lat. $39^{\circ} 20^{\prime} 30^{\prime \prime}$ N., long. $33^{\circ} 29^{\prime} 40^{\prime \prime}$ W., on flotsam).Ortmann, 1894, p. 710 (Oran; Africa; Atlantic Ocean; "Sargasso").Nutting, 1895, p. 29 (Gulf Stream, in Sargassum).-Hodgson, 1896, p. 178 (Plymouth Sound, England, on bottom of ship from Iquique, Peru; English Channel, 2-3 miles off Plymouth, on fragment of cork structure).-MilneEdwards, A., and Bouvier, 1899 , p. 37 (lat. $37^{\circ} 16-39^{\prime}$ N., long. $27^{\circ} 05-58^{\prime}$ W., on turtles, Thalassochelys caretta; lat. $39^{\circ} 12^{\prime}$ N., long. $33^{\circ} 09^{\prime}$ W., on flotsam; lat. $38^{\circ} 08^{\prime}$ N., long. $25^{\circ} 55^{\prime}$ W., on flotsam; lat. $38^{\circ} 26^{\prime}$ N., long. $28^{\circ} 51^{\prime}$ W.); 1900 , p. 108 (off Ponte-Delgado, on Sargassum).-Rankin, 1900 , p. 526 (Bermuda, in tide-pools with Pachygrapsus among Sargassum). -Young, 1900, p. 286 (part: not all distribution records).-Howe, 1900, p. 240 (approx. lat. $40^{\circ}$ N., long. $70^{\circ}$ W.).-Norman and Scott, 1906, p. 5.Bouvier, 1907, p. 37 (variable coloration).-Coulon, 1907, p. 123 [17] (Sargasso Sea).-Norman, 1907, p. 357 (Channel Islands).-Stimpson, 1907, p. 121 (North Atlantic, between lat. $20-36^{\circ}$ N., common on floating logs, seaweed (Sargassum), etc.).-Norman and Brady, 1909, p. 9.-Pesta, 1918, p. 446, fig. 147 (Lesina).-Boraschi, 1921, p. 10, pl. 1, fig. 9 (larvae: Quarto dei Mille; Palermo).-Miranda y Rivera, 1921, p. 189 (Playa de la Malagueta, Spain).-Monod, 1932, p. 219 (Fedhala, Morocco, common on marine plants and other objects).

Nautilograpsus major Macleay, 1838, p. 66 (Cape of Good Hope).-Krauss, 1843, p. 44.-Milne-Edwards, H., 1852, p. 175.

Nautilograpsus smithii Macleay, 1838, p. 67 (Cape of Good Hope).-Krauss, 1843, p. 44.-Milne-Edwards, H., 1852, p. 175.

Grapsus diris Cost八, 1838-53, [p. 2, pl. 4, fig. 1 (color)] (Naples, "among rocks above water").-Milne-Edwards, H., 1852, p. 175.

Planes linnaeana LEACH, 1815, pl. 27, figs. 1-3, and accompanying text (coasts of Devon and Cornwall).-Bell, 1844-53, p. 135, figs. (Devonshire; Cornwall).-White, 1847, p. 41 (Devonshire; south Atlantic).-Cocks, 1849, p. 80 (Falmouth, England, from stomach of fish).-White, 1850, p. 19 (Devonshire).-Gosse, 1855, p. 159, fig. 302.-McAndrew, 1860, p. 21.Lukis and Le Lievre, 1862, p. 232 (Guernsey, Channel Islands).-MarCUSEN, 1867, p. 359 (Black Sea).-CARRINGton and Lovett, 1882, p. 181 (Looe, Cornwall, among stalked barnacles on timber; Penzance, from soil and seaweed on derelict cask of paraffin).-ConNIsH, 1882, p. 118 (off Penzance, England, from soil and seaweed growing on derelict cask of paraffin); 1884, p. 116 (near Penzance, England, from derelict water-logged barrel of paraffin drifted ashore).

Planes minutus Whiте, 1847, p. 42 ("Gulf of Florida;" Atlantic Ocean, on gulfweed).-Dana, $1852 b$, p. $346 ; 1854$, p. 27.-Cunningham, 1870 , p. 493 
(south of Azores, on Sargassum); 1871, p. 501.-Ratнвun, 1897b, p. 29 (Kingston Harbor, Jamaica); 1898a, p. 288 (Dry Tortugas, in gulfweed; lat. $31^{\circ} 30^{\prime}$ N., long. $75^{\circ} 11^{\prime}$ W.) ; 1898 b, p. 604 , (part: lat. $31^{\circ} 16^{\prime}$ N., long. $71^{\circ} 50^{\prime}$ W.).-OrtmanN, 1899, p. 1188 (part).-RAthBun, 1900a, p. 279; 1900b, p. 587 (part).-Thompson, D'A. W., 1901, p. 6 (Atlantic).-Borradalle, 1903, p. 432 (Male, Maldive Islands, on floating cuttlebone).-DofLEIN, 1904 , p. 130 (lat. $30^{\circ} 6.7^{\prime}$ S., long. $87^{\circ} 50.4^{\prime}$ E.).-MAYER, 1905 , p. 102 Stebbing, 1905, p. 43 (False Bay, South Africa).-Rathbun, 1905, p. 4 (Woods Hole and Wareham, Mass.; Sakonnet Point, R. I., under rocks).Nobili, 1906, p. 321 (Djibouti).-Verrill, 1908, p. 325, fig. 7, pl. 13, figs. $a-j^{\prime}$, pl. 27, fig. 6 (off Bermuda).-Lenz, 1910, pp. 560, 574 (Ste. Marie, Madagascar).-Stebring, 1910, p. 320 (South Africa: False Bay; 38 miles northwest of Rable Bay).-Doflein and BALss, 1912, p. 39 (part ?: lat. $44^{\circ} 32^{\prime}$ S., long. $61^{\circ} 25^{\prime}$ W.).-Fowler, 1912 , p. 443 , pls. $140-141$ (Cape May, N. J.).-Murray and HJort, 1912, pp. 103, 633, 671, pl. 6 (color) (approx. lat. $36^{\circ} 05^{\prime}$ N., long. $43^{\circ} 58^{\prime}$ W.).-Pesta, 1912, p. 122 (Lesina).-SUMner, Osburn, and Cole, 1913, p. 675 (western part of Vineyard Sound, Mass., commonly on gulfweed).-Lenz and Strunck, 1914, p. 284 (off Madeira, on floating weed; off New Amsterdam Island, on Macrocystis; southeast of Madagascar; south of Azores, on Sargassum).-Stebing, 1914a, p. 345 (Falkland Islands); 1914b, p. 266, pl. 24 (Saldanha Bay, South Africa; lat. $29^{\circ} 54^{\prime}$ N., long. $34^{\circ} 10^{\prime}$ W. to lat. $33^{\circ} 53^{\prime}$ N., $32^{\circ} 27^{\prime}$ W.).-Bouvier, 1915 , p. 127 (Port Louis, Mauritius).-HAY and Shore, 1918, p. 448, pl. 36, fig. 6 (Beaufort, N. C.).--Rathbun, 1918, p. 253 (part: off Woods Hole, Mass., to Florida and Bahamas; Azores; Indian Ocean; Kerguelen Island).-Tesch, 1918 , p. 83 [footnote] (part: not all distribution records).-Crozien, 1918, pp. 262-263 (Bermuda, on floating tree; coloration).-LUEDERWALDT, 1919, p. 435 (Iguape, São Paulo, Brazil).-BAlss, 1922a, p. 83 (Monrovia, West Africa).-Bouvier, 1922 , p. 74 , pl. 2, fig. 2 (color) (east-central North Atlantic between lat. $28^{\circ}$ and $39^{\circ} \mathrm{N}$., and long. $23^{\circ}$ and $43^{\circ} \mathrm{W}$., on turtles, Sargassum, floating wood, etc.).-Hyman, 1924, p. 5, pl. 1, figs. 1-10 (Beaufort Harbor, N. C.).-RATH BUN, 1924, p. 157 (off eastern Cuba, on Sargassum). -Monod, 1927, p. 621 (Souelaba, Douala Bay, Cameroon, on floating tree trunk).-Perkins, 1928, p. 53.-RAthbun, 1929, p. 35, fig. 48 (off Nova Scotia).-Nobre, 1931, p. 107, figs. 60-63 (Douro River, Portugal, on root of tree washed in by storm).-Monod, 1933, p. 80.-RATHBUn, 1933, p. 89, fig. 83 (Puerto Rico; St. Thomas).--Екмan, 1935, pp. 9, 425 (part, not fig.).Noвre, 1936, p. 63 , pl. 24, fig. 45, pl. 46, fig. 45a.-Monod, 1939, p. 567 (lat. $30^{\circ} 10^{\prime}$ N., long. $47^{\circ}$ W., on Sargassum).-Bouvier, 1940, p. 291, fig. 182.- Нгтснсоск, H. B., 1941, pp. 26-30 (Bermuda; color change).-LEBour, 1944, p. 114, fig. 4 (Bermuda, in Sargassum; larvae).-Zariquiey Alvarez, 1946, p. 163, pl. 18, fig. b.

Nautilograpsus diris Heller, 1863, p. 115.

Nautilograpsus pelagicus Heller, 1863, p. 115.

Nautilograpsus cyaneus TARgioni Tozzetri, 1872, p. 8 (Sargasso Sea); 1877, p. 125, pl. 8, figs. $5 a-f$ (Atlantic Ocean). Not Planes cyaneus Dana, 1852.

Planes linneana Couch and BATE, 1878, p. 469 (English Channel off French coast, under tail of hawksbill turtle; Devon or Cornwall).

Nautilus grapsus minutus Morison, 1942, p. 269.

Planes sp. Whiтe, 1847, p. 42 (St. Kitts Island; Falkland Islands; Brazil; Swan River).-Beebe, 1932, pp. 188-196 (Bermuda).

Nautilograpsus sp. Müller, F., 1881, p. 473 (color change). 


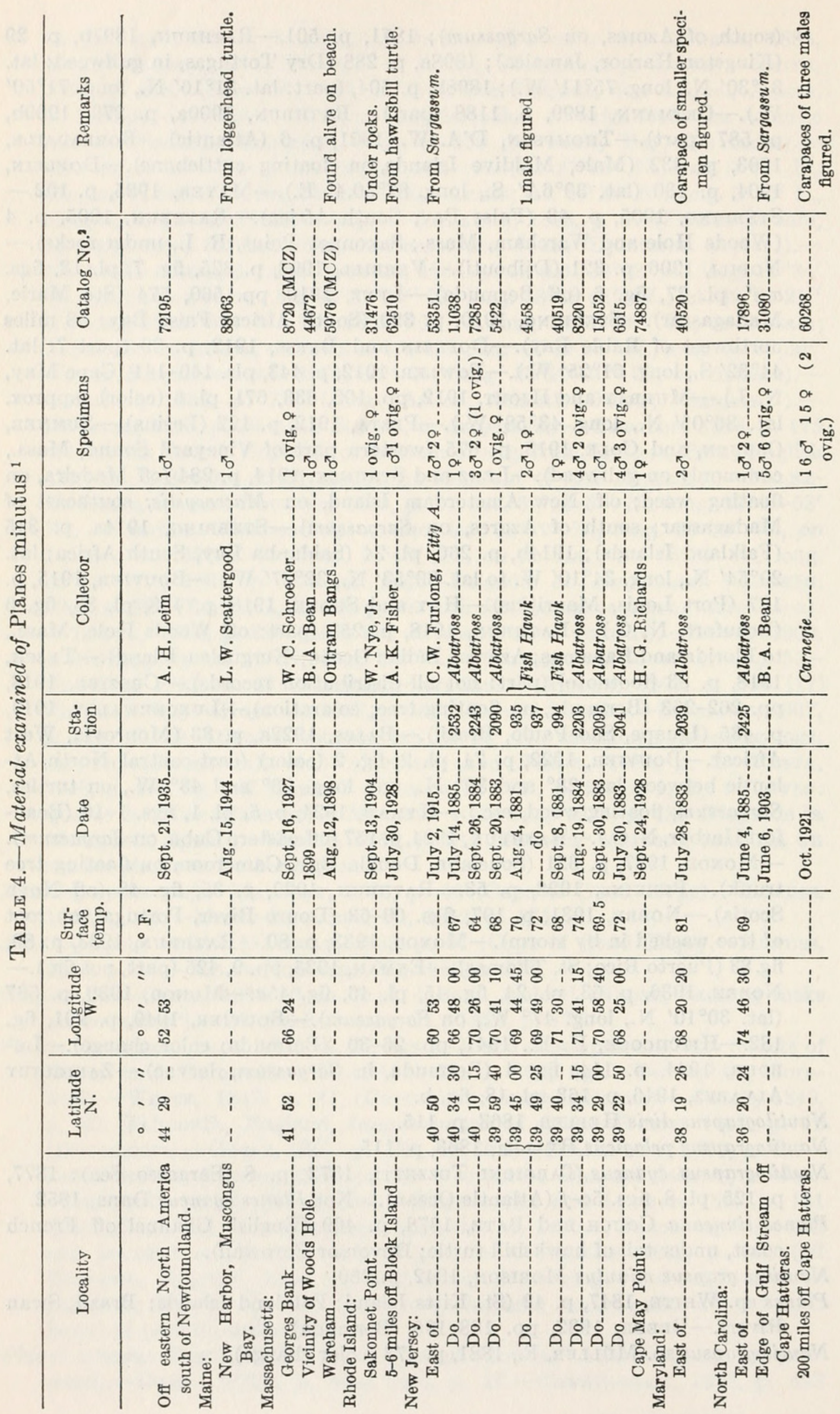


CRAB GENERA PLANES AND PACHYGRAPSUS-CHACE

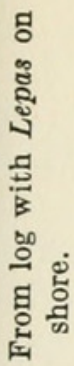

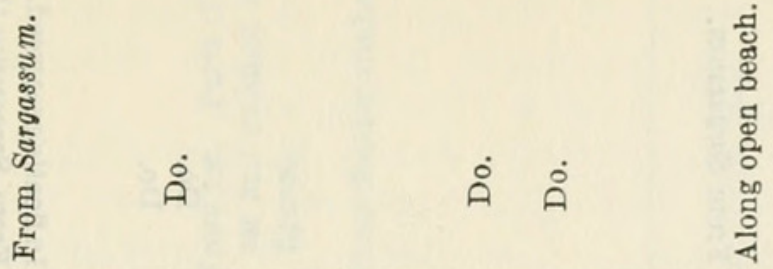

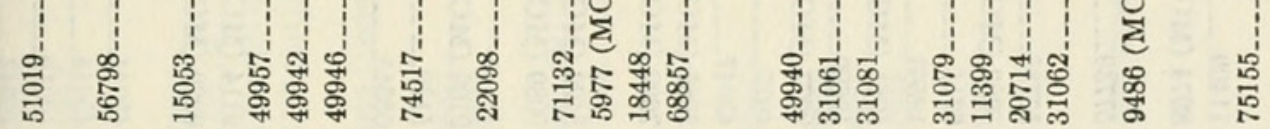

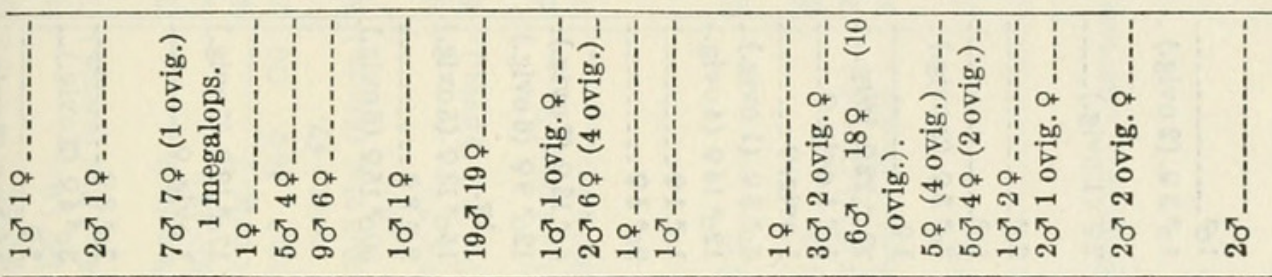

.

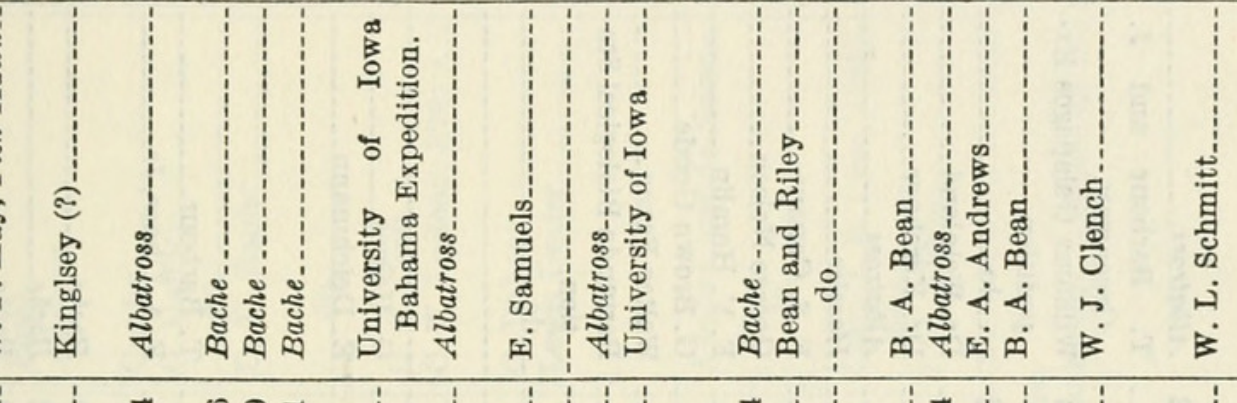

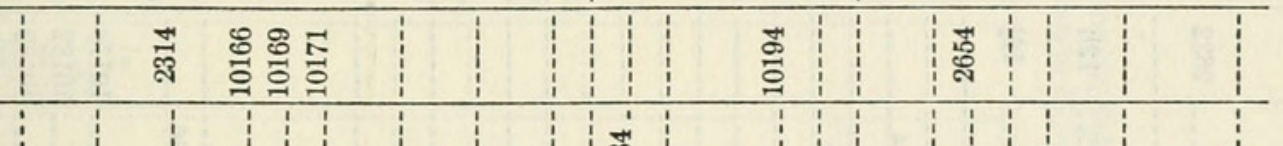

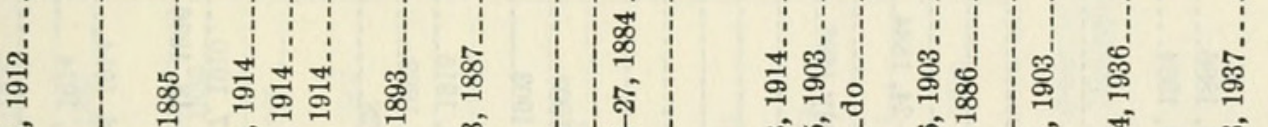

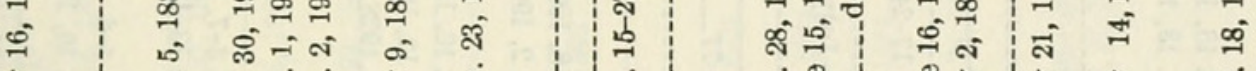

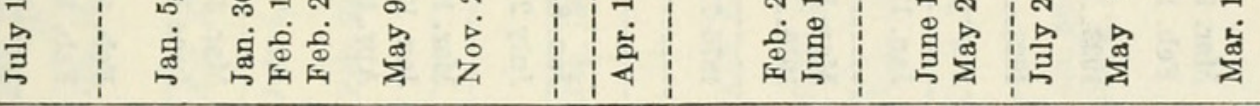

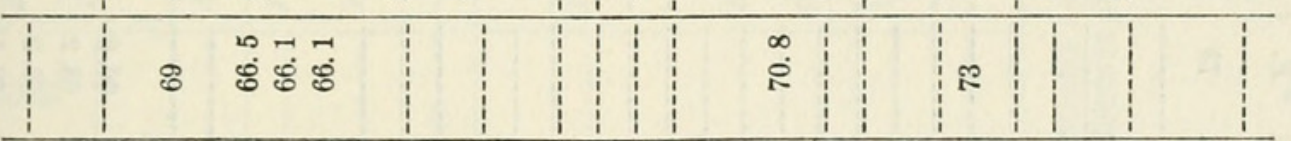

\begin{tabular}{|c|c|c|c|c|c|c|c|c|}
\hline i & $i$ & 8 & $11:$ & i & i & $1: i$ & $1: 1$ & i̊ : 1 \\
\hline ; & : & 5 & ザ \& & $\Rightarrow$ & in & i i i i & $\dddot{m}:$ & !ล ! ! \\
\hline i & ; & N & ำ & 웅 & $B$ & $i \quad i \quad i$ & ํㅜㄴ & i尺 \\
\hline i & : & 8 & : $: 1$ & i & : & $1 ; 1 ;$ & $1:$ i & : \\
\hline i & i & æ & ๓ ฉ ล & ఃి & 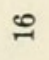 & : 111 & ह5: & is i i \\
\hline I & i & ศ్ & స్ న్ల స్ల & के & ल & $1 ; i$ & న & !ล ! ! \\
\hline
\end{tabular}

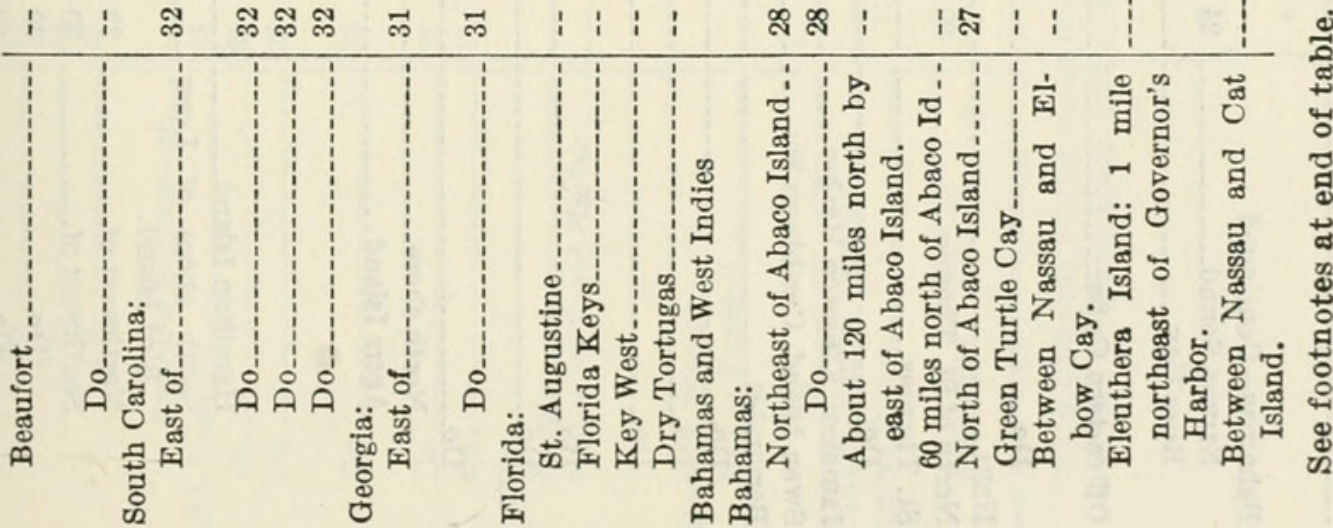




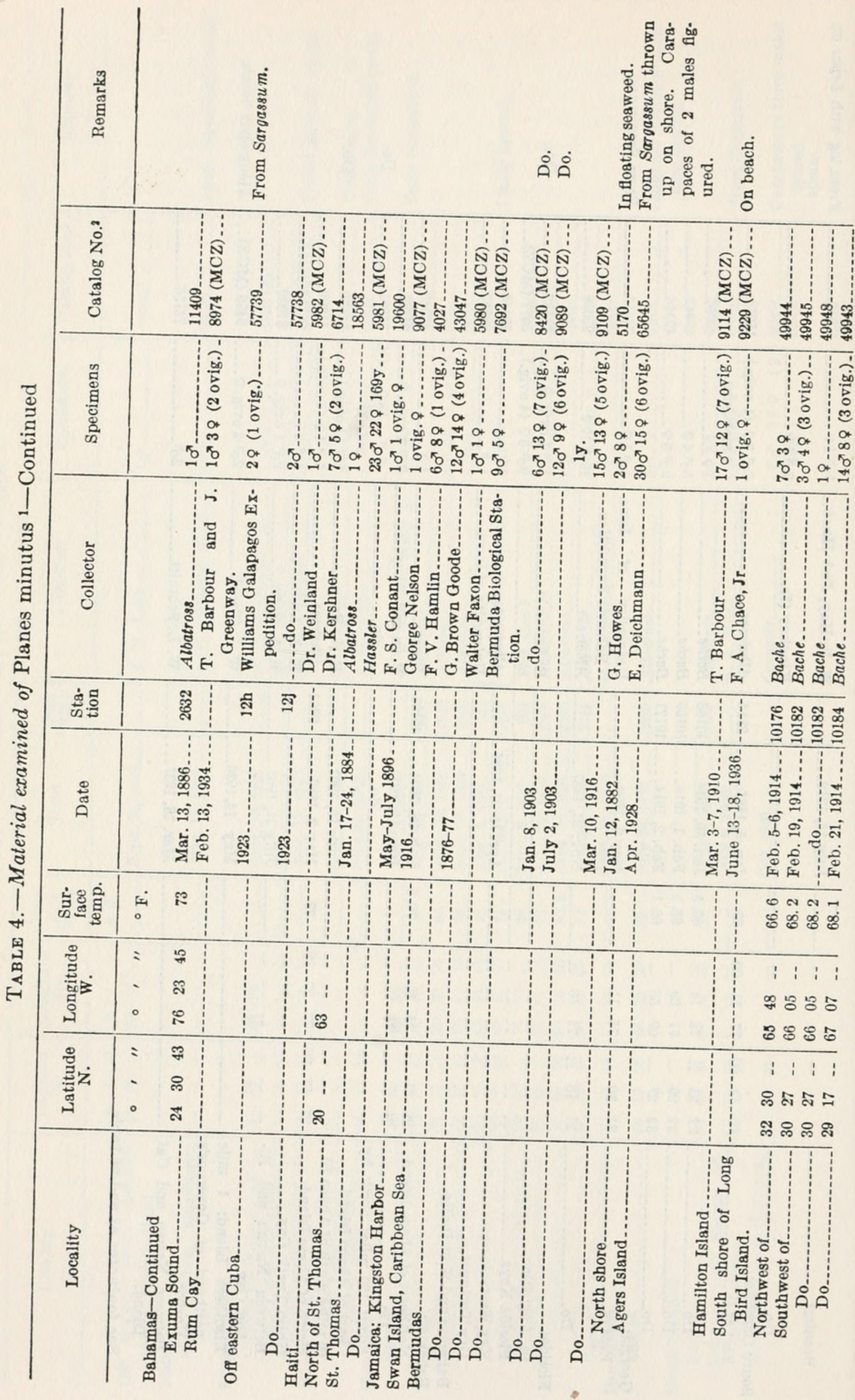




\section{PLANES CYANEUS Dana}

Cancer cantonensis Linnaeus, 1747, p. 137, pl. 1, figs. 1a-b (Canton [?]).

Grapsus pusillus HAAN, 1835, p. 59, pl. 16, fig. 2.-Milne-Edwards, H., 1852, p. 175. Not Cancer pusillus Fabricius, 1775.

Nautilograpsus minutus Milne-Edwards, H., and LuCas, 1843, p. 28 (record from off Valparaiso credited to Eydoux).-Nicolet, 1849, p. 168 (Valparaiso Bay).--Jacquinot and Lucas, 1853, p. 78 (Port Famine, Straits of Magellan, very abundant).-Stimpson, 1860, p. 231 [103] (Cape San Lucas, Baja California).-MAN, 1879, p. 69 (part: Japan; New Guinea).-KingsLeY, 1881, p. 202 (part: Peru; west coast of Mexico; Alaska; China; New Zealand; Falkland Ids. [?]).-Miens, 1886, p. 254 (part: South Pacific, near Kermadec Islands, among seaweed; North Pacific, off Volcano Island; off Japan).Lenz, 1901, p. 472 (between Honolulu and San Francisco). Not Cancer minutus Linnaeus, 1758.

Planes cyaneus DANA, $1852 \mathrm{a}$, p. 250 (lat. $28^{\circ}$ N., long. $174^{\circ}$ E.); $1852 \mathrm{~b}$, p. 347 (lat. $15^{\circ} 50^{\prime}$ S., long. $105^{\circ}$ W.) ; 1853 , p. $1593 ; 1855$, pl. 22 , fig. 1.-WARD, 1939 , p. 14 (lat. $29^{\circ} 20^{\prime}$ N., long. $141^{\circ} 25^{\prime}$ W.).

Nautilograpsus angustatus Stmpson, 1858 , p. 103 [49] (lat. $34^{\circ}$ N., long. $155^{\circ}$ E.); 1907 , p. 121 , pl. 16 , fig. 1 (lat. $34^{\circ}$ N., long. $151^{\circ}$ W.).

Planes minutus Miers, 1876, p. 39 (New Zealand).-HASwell, 1882, p. 99.Filhol, 1885 , p. $390 .-F_{\text {AXoN, }} 1895$, p. 30 (lat. $00^{\circ} 13^{\prime} 00^{\prime \prime}$ S., long. $84^{\circ} 52^{\prime} 00^{\prime \prime}$ W.; lat. $2^{\circ} 34^{\prime} 00^{\prime \prime}$ N., long. $92^{\circ} 06^{\prime} 00^{\prime \prime}$ W.; off Acapulco, Mexico; all on green turtles).-RATHBUN, $1898 \mathrm{~b}$, p. 604 (part: lat. $1^{\circ} 03^{\prime}$ N., long. $80^{\circ} 15^{\prime}$ W.; Gulf of California).-Ortmann, 1899, p. 1188 (part).-Rathbun, 1900 b, p. 587 (part); 1902, p. 278 (about 200 miles north of Wenman Island, Galápagos, at base of tail of green turtle); 1904 , p. 189 (lat. $41^{\circ}$ N., long. $141^{\circ}$ W.; Point Loma, Calif.; off San Diego, Calif.).-Fulton and Grant, 1906, p. 19.-RAthbuN, 1906, p. 840 (between Erben Bank and Kaiwi Channel, on Velella: south coast of Oahu Island; south coast of Molokai Island, on floating stick).-RAтHBUN, 1907, p. 69 (south of Gulf of California; off Guatemala; off Peru); 1910, pp. 589, 610-614, 616.-Wеумочтн, 1910 , p. 63 , pl. 14, fig. 44.-Chilton, 1911, p. 561 (Kermadec Islands).Doflein and Balss, 1912, p. 39 (part: Smith Channel, Straits of Magellan).Rathbun, 1918, p. 253, pl. 63 (part: Humboldt Bay, Calif., to Peru; Galápagos Islands; Hawaiian Islands; Marquesas Islands; Japan; Mauritius).Tesch, 1918, p. 83 [footnote] (part).-Sснмiтt, 1921, p. 272, pl. 46, figs. 1-2 (La Jolla, Calif.; off Point Loma, Calif.).-BALss, 1922b, p. 149 (Ogasawara Island).-BALss, 1924, p. 336 (Juan Fernández Island).-URITA, 1926, p. 23 (off Ohsima, Ohsumi, Japan).-HALE, 1927, p. 181, fig. 182.-Chilton and Bennett, 1929, p. 768 (Moko Hinau, New Zealand, washed ashore on piece of pumice).-Sivertsen, 1933, p. 21.-Glassell, 1934, p. 302 (Gulf of California).-SAKaI, 1934, p. 323 (Japan).-EkmaN, 1935, p. 9, fig. 3 (not p. 425).-SAKAI, 1936, p. 226, fig. 120 (Japan).-AIKAWA, 1937, p. 152 (larvae).Crane, 1937, p. 77 (Santa Inez Bay, Mexico, on tail of green turtle; food).SAKAI, 1939, p. 664, pl. 108, fig. 2 (Misaki, from turtle; Odawara, Sagami Bay; Simoda, on Sargassum; Ise Bay; Seto; Tosa Bay; Nagasaki; northern Daitozima; Tansui, Formosa).--Stein веск and Ricketts, 1941, pp. 45, 474 (south of Point Abrojos, Baja Calif., in folds of skin beside tail of tortoiseshell turtle, Eretmochelys imbricata [on flipper, p. 474]).-Edmondson, 1946, p. 306, fig. 183f (Hanauma Bay, Oahu Island).-Pope, 1948, pp. 296-297, fig.-Richardson, 1949, p. 34, pl. 2, fig. 16. Not Cancer minutus Linnaeus, 1758. Nautilograpsus pusillus MaN, 1879, p. 69. Not Cancer pusillus Fabricius, 1775. Planes marinus WARD, 1939 , p. 14 (lat. $32^{\circ} 00^{\prime}$ N., long. $135^{\circ} 20^{\prime}$ W.; lat. $29^{\circ} 20^{\prime}$ N., long. $141^{\circ} 25^{\prime}$ W.). Not P. marinus Rathbun, 1914. 


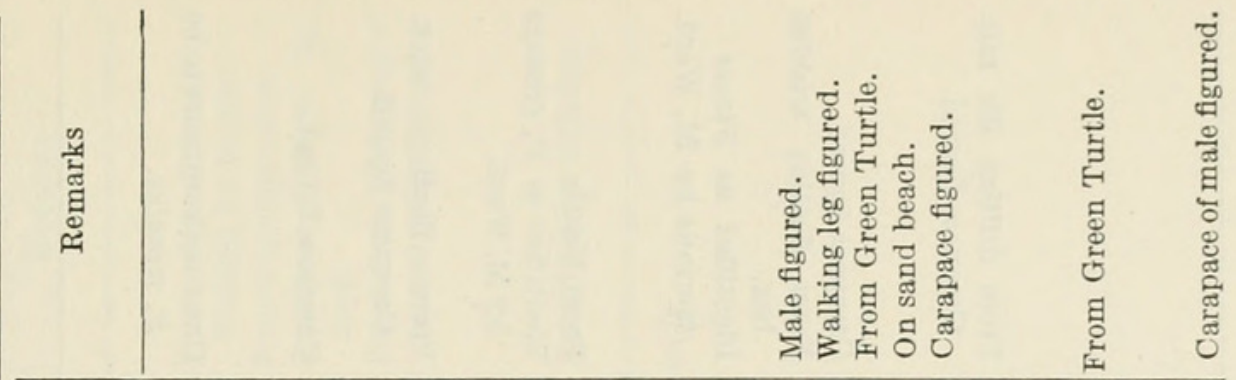

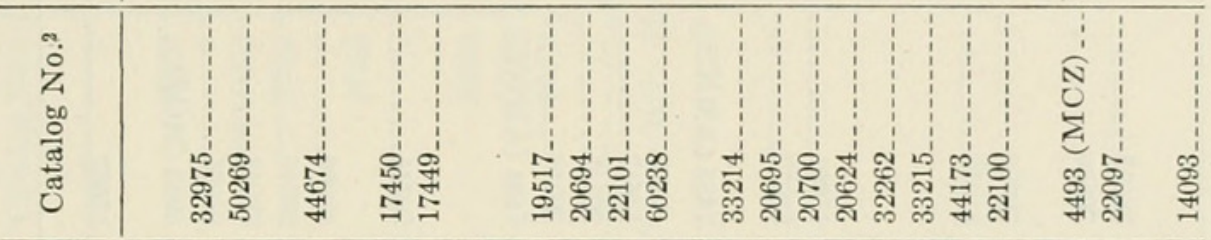

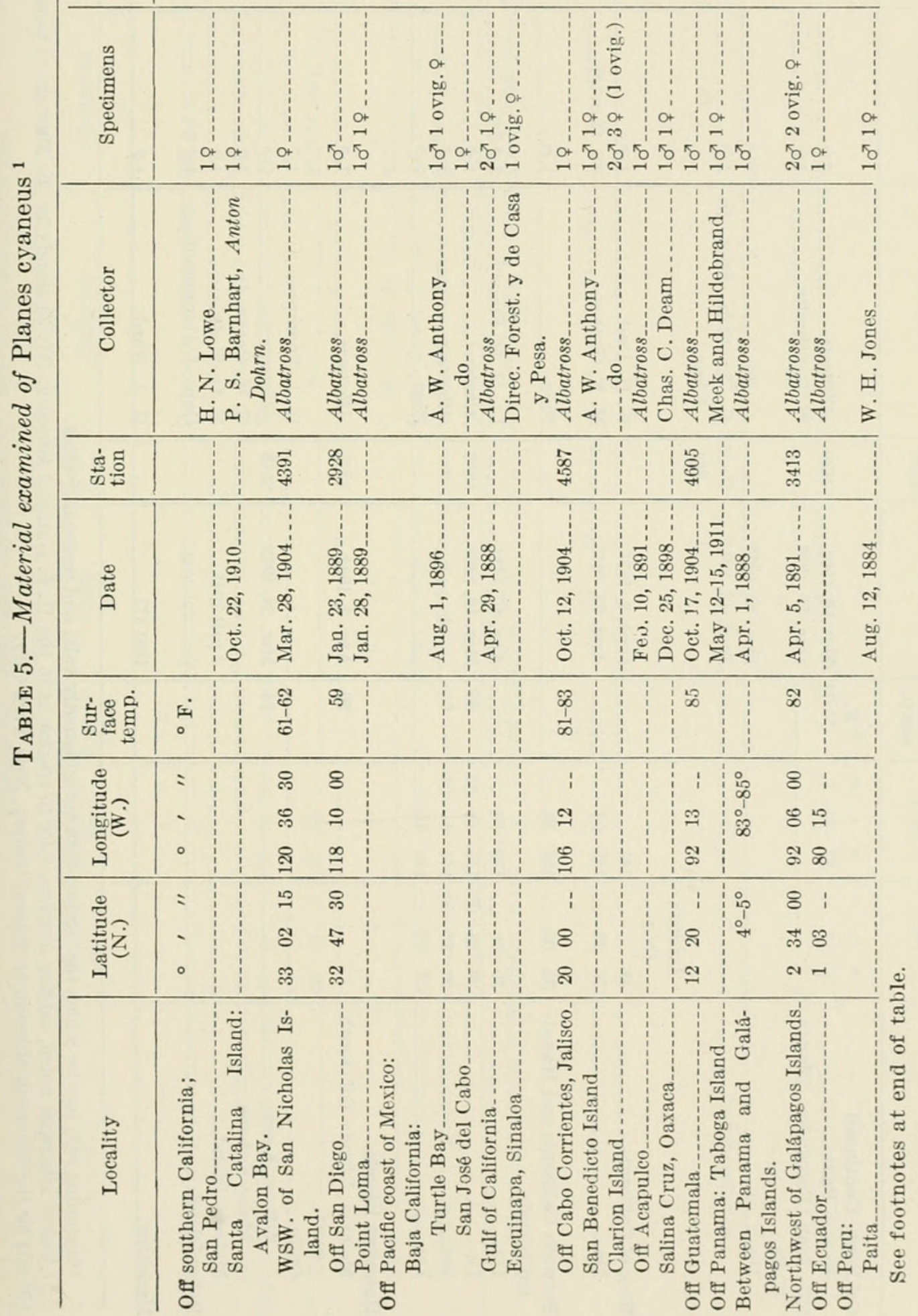




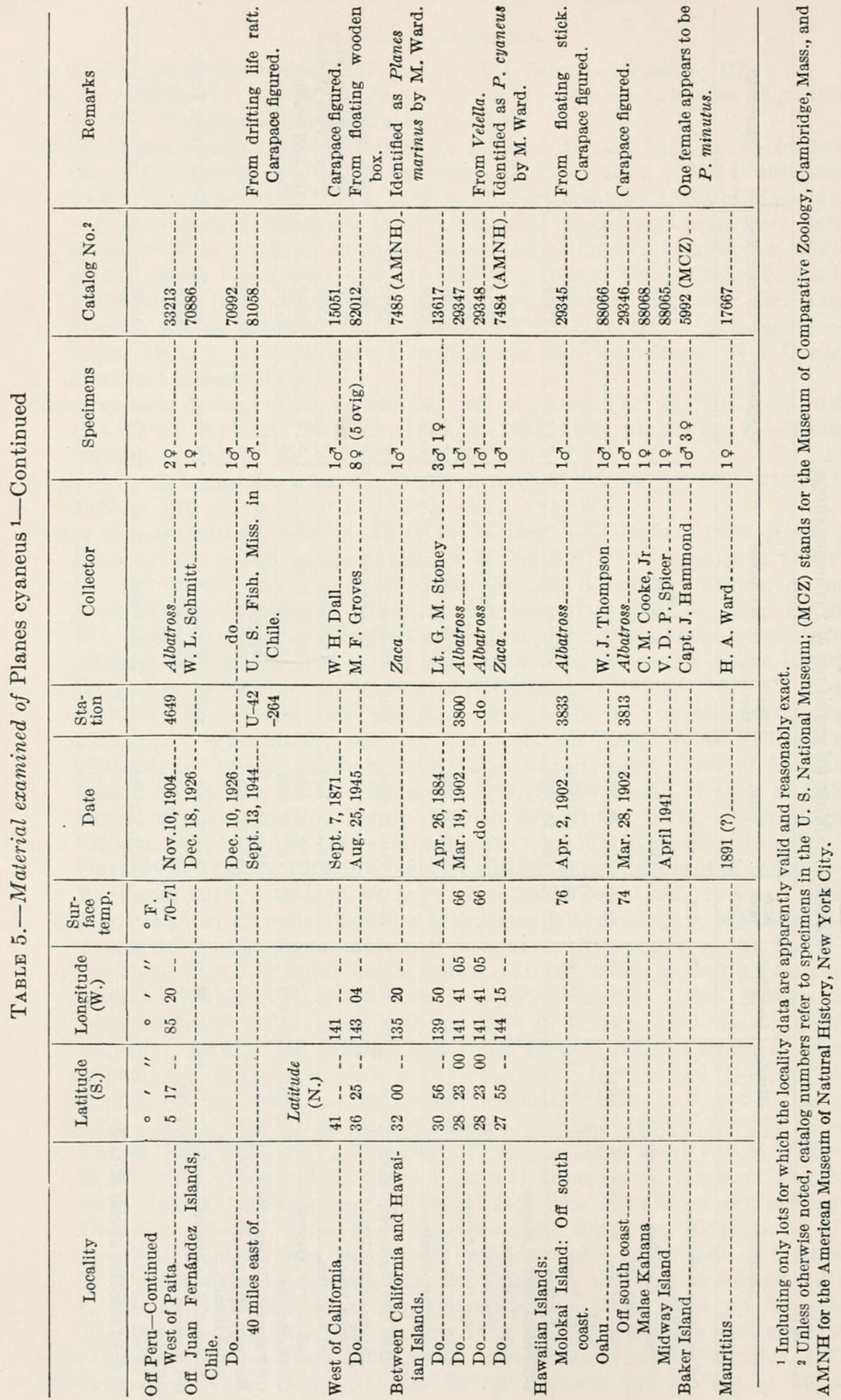




\section{Genus PACHYGRAPSUS Randall}

\section{PACHYGRAPSUS MARINUS (Rathbun)}

Planes marinus Rathвun, 1914, p. 120 , pl. 3 (lat. $23^{\circ} 49^{\prime}$ N., long. $127^{\circ} 50^{\prime}$ W.); 1918, p. 258, pl. 64.-Tesch, 1918, p. 83 [footnote].-Glassell, 1934, p. 302.

\section{LITERATURE CITED}

Aikawa, Hiroaki.

1937. Further notes on brachyuran larvae. Rec. Oceanogr. Works in Japan, vol. 9, No. 1, pp. 87-162, 36 figs.

Alcock, Alfred William.

1900. Materials for a carcinological fauna of India, No. 6: The Brachyura Catometopa or Grapsoidea. Journ. Asiatic Soc. Bengal, vol. 69, pt. 2 No. 3, pp. 279-456.

Balss, Heinrich.

1922a. Crustacea VII: Decapoda Brachyura (Oxyrhyncha und Brachyrhyncha) und geographische Übersich über Crustacea Decapoda. In Michaelsen's "Beiträge zur Kenntnis der Meeresfauna Westafrikas," vol. 3, Lief. 3, pp. 71-110, 1fig.

1922b. Ostasiatische Decapoden, IV: Die Brachyrhynchen (Cancriciea). Arch. Naturg., Jahrg. 88, Abt. A, Heft 11, pp. 94-166, 2 figs., 2 pls.

1924. Decapoden von Juan Fernandez. In Skottsberg's "The Natural History of Juan Fernandez and Easter Island," vol. 3, pp. 329-340, 3 figs.

Barrois, Théodore.

1888. Catalogue des Crustacés marins recueillis aux Açores durant les mois

Beebe, William. d'Août et de Septembre 1887, 110 pp., 8 figs., 4 pls. Lille.

1932. Nonsuch: Land of water, $x v+259$ pp., 46 figs., frontis. New York.

Bell, Thomas.

1844-53. A history of the British stalk-eyed Crustacea, lxv +386 pp. London.

Boraschi, Lillia.

1921. Osservazioni sulle larbe dei crostacei decapodi brachiuri e anomuri. R. Comitato Talassografico Italiano, Mem. 87, 32 pp., 2 pls.

Borradaile, Lancelot Alexander.

1903. Marine crustaceans, pt. 5: The crabs of the catometope families. In Gardiner's "The Fauna and Geography of the Maldive and Laccadive Archipelagoes," pp. 429-433, 4 figs. Cambridge.

Bosc, Louis A. G.

1801-02. Histoire naturelle des crustacés, contenant leur description et leurs moeurs; avec figures dessinées d'après nature, vol. 1, 258 pp. Paris.

Bouvier, Eugìne Louis.

1907. Quelques impression d'un naturaliste au cours d'une campagne scientifique de S. A. S. le Prince de Monaco (1905). Bull. Inst. Océanogr. Monaco, No. 93, 103 pp., 69 figs.

1915. Décapodes marcheurs (Reptantia) et stomatopodes recueillis à l'îleMaurice par M. Paul Carié. Bull. Sci. France et Belgique, ser. 7, vol. 48 , fasc. 3,141 pp., 42 figs., 4 pls.

1922. Observations complémentaires sur les crustacés décapodes (abstraction faite des carides) provenant des campagnes de S. A. S. le Prince de Monaco. Rés. Camp. Sci. Monaco, fasc. 62, 106 pp., 6 pls.

1940. Décapodes marcheurs. Faune de France, vol. 37, 404 pp., 222 figs., 14 pls. Paris. 
Bowdich, Thomas Edward.

1825. Excursions in Madeira and Porto Santo during the autumn of 1823, Brocchi, PaUL. while on his third voyage to Africa, xii +278 pp., 22 pls. London.

1875. Recherches sur les organes génitaux males des crustacés décapodes. Ann. Sci. Nat., Zool., ser. 6, vol. 2, art. 2, 131 pp., 7 pls.

Browne, Patrick.

1789. The civil and natural history of Jamaica, viii +503 pp., 49 pls., 1 map. London.

CANo, G.

1891. Sviluppo postembrionale dei dorippidei, leucosiadi, corystoidei e grapsidi. Mem. Soc. Ital. Sci., vol. 8, ser. 3, No. 4, 14 pp., 3 pls.

Carrington, John Thomas, and Lovett, Edward.

1882. Notes and observations on British stalk-eyed Crustacea. Zoologist, ser. 3, vol. 6, pp. 178-185.

Carus, Julius Victor.

1885. Coelenterata, Echinodermata, Vermes, Arthropoda. Prodromus faunae Mediterraneae sive descriptio animalium Maris Mediterranei incolarum quam comparata silva rerum quatenus innotuit adiectis locis et nominibus vulgaribus eorumque auctoribus in commodum zoologorum, vol. 1 , xi+524 pp. Stuttgart.

Chevreux, Edouard and Guerne, Jules de.

1893. Crustacés et cirrhipèdes commensaux des tortues marines de la Méditerranée. Comptes Rendus Acad. Sci. Paris, vol. 116, pp. 443-446.

Chilton, Charles.

1911. The Crustacea of the Kermadec Islands. Trans. New Zealand Inst., vol. 43 , art. 49 , pp. 544-573, 4 figs.

Chilton, Charles, and Bennett, E. W.

1929. Contributions for a revision of the Crustacea Brachyura of New Zealand. Trans. New Zealand Inst., vol. 59, pp. 731-778.

Cocks, W. P.

1849. Contributions to the fauna of Falmouth. Ann. Rep. Royal Cornwall Polytechnic Soc., pp. 38-102.

Cornish, Thomas.

1882. Floating crab at Penzance. Zoologist, ser. 3, vol. 6, No. 63, p. 118.

1884. Floating crabs at Penzance. Zoologist, ser. 3, vol. 8, p. 116.

Costa, Oronzio Gabriele.

1838-53? Crostacei ed aracnedi. Fauna del Regno di Napoli ossia enumerazione di tutti gli animali che abitano le diverse regioni di questo regno e le acque che le bagnano contenente la discrizione de nuovi o poco esattamente conosciuti, 290 pp., 29 pls.

Couch, Junathon, and Bate, C. Spence.

1878. Crustacea: A Cornish fauna. Journ. Roy. Inst. Cornwall, No. 19, pt. 2, pp. 451-522.

Coulon, Louis.

1907. Les crustacés du Musée d'Histoire naturelle d'Elbeuf, pt. 2: Les malacostracés. I. Thoracostracés (podophthalmaires). Bull. Soc. Étud. Sci. Nat. Elbeuf, vol. 26, pp. 119-194, 1 pl.

Crane, Jocelyn.

1937. The Templeton Crocker Expedition, III: Brachygnathous crabs from the Gulf of California and the west coast of Lower California. Zoologica, New York, vol. 22, pt. 1, No. 3, pp. 47-78, 8 pls. 
Crozier, William John.

1918. On the coloration of Planes minutus. Amer. Nat., vol. 52, No. 616, pp. 262-263.

Cunningham, Robert Oliver.

1870. Notes on the Reptiles, Amphibia, Fishes, Mollusca, and Crustacea obtained during the voyage of H. M. S. Nassau in the years 1866-69. Trans. Linn. Soc. London, vol. 27, pp. 465-502, 2 pls.

1871. Notes on the natural history of the Strait of Magellan and west coast of Patagonia, made during the voyage of H. M. S. Nassau in the years $1866,67,68, \& 69$, xvii +517 pp., 20 pls., 1 map. Edinburgh.

Czerniavsky, Voldemar.

1884. Materialia ad zoographiam Ponticam comparatam, fasc. 2: Crustacea decapoda Pontica littoralia. Trav. Soc. Univ. Kharkov, vol. 13, suppl., 268 pp., 7 pls.

Dana, James Dwight:

1851. On the classification of the Crustacea Grapsoidea. Amer. Journ. Sci. and Arts, vol. 12, ser. 2, pp. 283-291.

1852a. Conspectus crustaceorum quae in orbis terrarum circumnavigatione, Carolo Wilkes e classe Reipublicae Faederatae duce. Proc. Acad. Nat. Sci. Philadelphia, vol. 5, 1850-51, pp. 247-254.

1852b. Crustacea (pt. 1). U. S. Exploring Expedition, vol. 13, pp. i-viii, 1-685.

1853. Crustacea (pt. 2). U. S. Exploring Expedition, vol. 14, pp. 686-1618.

1854. On the geographical distribution of Crustacea. Amer. Journ. Sci and Arts, ser. 2, vol. 18, pp. 1-45, 1 map.

1855. Crustacea. U. S. Exploring Expedition, atlas, 27 pp., 96 pls.

De Kay, James Elsworth.

1844. Zoology of New-York or the New-York fauna, pt. 6: Crustacea, 70 pp, 13 pls. Albany.

Doflein, Franz.

1904. Brachyura, Wiss. Ergebn. Deutsch. Tiefsee-Exped. Valdivia, vol. 6, xiv +314 pp., 68 figs., 58 pls.

Doflein, Franz, and Balss, Heinrich.

1912. Die dekapoden und stomatopoden der Hamburger Magalhaensischen Sammelreise 1892/93. Jahrb. Hamburg. Wiss. Anst., vol. 29, pp. 25-44, 4 figs.

Edmondson, Charles Howard.

1946. Reef and shore fauna of Hawaii. Bernice P. Bishop Museum Special Ekman, Sven. Publ. 22, iii +381 pp., 223 figs.

1935. Tiergeographie des meeres, xii +542 pp., 244 figs. Leipzig.

Fabricius, Johannes Christian.

1775. Systema entomologiae, sistens insectorum classes, ordines, genera, species, adjectis synonymis, locis, descriptionibus, observationibus, 832 pp. Flensburg and Leipzig.

1781. Species insectorum exhibentes eorum differentias specificas, synonyma auctorum, loca natalia, metamorphosin adjectis observationibus, descriptionibus, vol. 1, viii +552 pp. Hamburg and Kiel.

1787. Mantissa insectorum sistens eorum species nuper detectas adiectis characteribus genericis, differentiis specificis, emendationibus, observationibus, vol. 1 , xviii $+348 \mathrm{pp}$. Copenhagen.

1793. Entomologia systematica, emendata et aucta. Classes, ordines, genera, species adjectis synonymis, locis, observationibus, descriptionibus, vol. 2, viii +519 pp. Copenhagen. 
Faxon, Walter.

1895. Reports on an exploration off the west coasts of Mexico, Central and South America, and off the Galapagos Islands, in charge of Alexander Agassiz, by the U. S. Fish Commission steamer, Albatross, during 1891, Lieut.-Commander Z. L. Tanner, U. S. N., commanding, 15: The stalk-eyed Crustacea. Mem. Mus. Comp. Zool., vol. 18,

Filhol, Henri. 292 pp., 6 figs., 66 pls., 1 chart.

1885. Catalogue des crustacés de la Nouvelle-Zélande, des Iles Auckland et Campbell. Recueil de mémoires, rapports et documents relatifs a l'observation du passage de Vénus sur le soleil. Mission de l'Ile Campbell. Zoologie, vol. 3, pt. 2, No. 1, pp. 349-510, 18 pls. Paris.

Fowler, Henry Weed.

1912. The Crustacea of New Jersey. Ann. Rep. New Jersey State Mus., 1911, pt. 2, pp. 29-650, 149 pls.

Fulton, S. W., and Grant, F. E.

1906. Census of the Victorian decapod Crustacea, pt. 1, (Brachyura). Proc. Roy. Soc. Victoria, new ser., vol. 19, pt. 1, art. 3, pp. 16-20.

Gibbes, Lewis R.

1850. On the carcinological collections of the cabinets of natural history in the United States, with an enumeration of the species contained therein, and descriptions of new species, $37 \mathrm{pp}$. Charleston.

Glassell, Steve Andrew.

1934. Affinities of the brachyuran fauna of the Gulf of California. Journ. Washington Acad. Sci., vol. 24, No. 7, pp. 296-302.

Goodsir, Harry D. S.

1845. Description of some animals found amongst the gulf-weed. Ann. Mag. Nat. Hist., vol. 15, No. 96, pp. 73-76, 1 pl.

Gosse, Philip Henry.

1855. A manual of marine zoology for the British Isles, $x i+203$ pp., 335

Gourret, Paul.

$$
\begin{aligned}
& \text { manual of marine zoology for the British Isles, xi+203 pp., } 335 \\
& \text { figs. London. }
\end{aligned}
$$

1888. Révision des crustacés podophthalmes de Golfe de Marseille, suivie d'un essai de classification de la class de crustacés. Ann. Mus. Hist. Nat. Marseille, Zool., vol. 3, pp. 1-212, 18 pls.

HAAN, W. DE.

1835. Crustacea. In Siebold's "Fauna Japonica," decas 2, pp. 25-64, 9

Hale, Herbert M.

$$
\text { pls. Leiden. }
$$

1927. The crustaceans of South Australia, 201 pp., 202 figs. Adelaide.

Haswell, William Aitcheson.

1882. Catalogue of the Australian stalk- and sessile-eyed Crustacea, xxiv + 324 pp., 8 figs., 4 pls. Sydney.

Hay, William Perry, and Shore, C. A.

1918. The decapod crustaceans of Beaufort, N. C., and the surrounding region. Bull. U. S. Bur. Fish., vol. 35, pp. 371-475, 20 figs., 15 pls.

Heilprin, Angelo.

1889. Contributions to the natural history of the Bermuda Islands. Proc. Acad. Nat. Sci. Philadelphia, 1888, pp. 302-328, 3 pls. 
Heller, Camil.

1863. Die Crustaceen des südlichen Europa, xi+336 pp., 10 pls. Vienna.

1865. Crustaceen. Reise der österreichischen Fregatte Novara um die Erde in den Jahren 1857, 1858, 1859 unter den Befehlen des Commodore B. von Wüllerstorf-Urbair: Zool. Theil, vol. 2, pt. 3, 280 pp., 25 pls. Vienna.

Herbst, Johann Friedrich Wilhelm.

1783. Versuch einer Naturgeschichte der Krabben und Krebse nebst einer systematischen Beschreibung ihrer verschiedenen Arten, vol. 1, Heft 2-5, pp. 87-182, 8 pls. Berlin and Stralsund.

HitchCock, Edward.

1835. Catalogues of the animals and plants of Massachusetts, with a copious index, $142 \mathrm{pp}$. Amherst.

HitchCock, Harold Bradford.

1941. The coloration and color changes of the gulf-weed crab, Planes minutus.

Hodgson, T. V. Biol. Bull. Woods Hole, vol. 80, No. 1, pp. 26-30.

1896. Nautilograpsus minutus, Milne Edwards: Faunistic notes. Journ. Mar. Biol. Assoc. United Kingdom, new ser., vol. 4, No. 2, p. 178.

Howe, Freeland, Jr.

1900. Report of a dredging expedition off the southern coast of New England, September, 1899. Bull. U. S. Fish Comm., vol. 19, 1899, pp. 237-240.

Hyman, OrRen Williams.

1924. Studies on larvae of erabs of the family Grapsidae. Proc. U. S. Nat. Mus., vol. 65 , art. 10,8 pp., 3 pls.

Jacquinot, Honoré and Lucas, Hippolyte.

1853. Crustacés. In Hombron and Jacquinot, "Voyage au pole sud et dans l'océanie sur les corvettes l'Astrolabe et la Zélée": Zool., vol. 3, 107 pp. Paris.

Kingsley, John Sterling.

1881. Carcinological notes, No. IV: Synopsis of the Grapsidae. Proc. Acad. Nat. Sci. Philadelphia, 1880, pp. 187-224.

Krauss, Ferdinand.

1843. Die Südafrikanischen Crustaceen, 68 pp., 4 pls. Stuttgart.

Latreille, Pierre André.

1802-03. Histoire naturelle, générale et particulière, des crustacés et des insectes, vol. 6, 391 pp., 14 pls. Paris.

Leach, William Elford.

1814. Crustaceology. In Brewster's "Edinburgh Encyclopedia," vol. 7, pp. 383-437.

1815. Malacostraca podophthalmata Britanniae, Nos. $18-19$, pls. $9 \mathrm{~A}, 24 \mathrm{~A}$, $27,34,35,37 \mathrm{C}, 45$. London.

Lebour, Marie Victoria.

1944. Larval crabs from Bermuda. Zoologica, New York, vol. 29, pt. 3, pp. 113-128, 19 figs.

Lenz, Heinrich.

1901. Ergebnisse einer Reise nach dem Pacific (Schauinsland 1896-1897): Crustaceen. Zool. Jahrb., Abt. Syst., vol. 14, pp. 429-482, 1 pl.

1910. Crustaceen von Madagaskar, Ostafrika und Ceylon. In Alfred Voeltzkow's "Reise in Ostafrika in den Jahren 1903-1905 mit Mitteln der Hermann und Elise geb. Heckmann Wentzel-Stiftung ausgeführt," Wiss. Ergebn., vol. 2, Syst. Arb., pp. 539-576, 4 figs. 
Lenz, Heinrich, and Strunck, K.

1914. Die Dekapoden der Deutschen Südpolar-Expedition 1901-1903, I: Brachyuren und Macruren mit ausschluss der Sergestiden. Deutsche Südpolar-Expedition 1901-1903, vol. 15, Zool. 7, pp. 261-345, 5 figs., 11 pls.

Linnaeus, Carl.

1747. Wästgöta-Resa, Pä Riksens Högloflige Ständers Befallning Förrättad är 1746, 284 pp., 5 pls. Stockholm.

1758. Systema naturae, ed. 10, vol. 1,824 pp. Stockholm.

1767. Systema naturae, ed. 12, vol. 1, pt. 2, pp. 533-1327. Stockholm.

Luederwaldt, Hermann.

1919. Lista dos crustaceos superiores (Thoracostraca) do Museu Paulista que foram encontrados no Estado de S. Paulo. Rev. Mus. Paulista, vol. 11 , pp. $429-435$.

LUKIS and Le LIEvRE.

1862. Stalk-eyed crustaceans. In Ansted and Latham, "The Channel Islands," pp. 232-234. London.

MacLeay, William Sharp.

1838. Illustrations of the Annulosa of South Africa, 75 pp., 4 pls. London. Man, Johannes Govertus de.

1879. On some new or imperfectly known podophthalmous Crustacea of the Leyden Museum. Notes Leyden Mus., vol. 19, pp. 53-73.

Marcusen, Johann.

1867. Zur Fauna des schwarzen Meeres. Vorläufige Mittheiling. Arch. Naturg., vol. 1, No. 4, pp. 357-363.

Markham, Clements Robert.

1893. The journal of Christopher Columbus (during his first voyage, 149293), and documents relating to the voyages of John Cabot and Gaspar Corte Real, liv+240 pp. Hakluyt Society, London.

Mayer, Alfred Goldsborough.

1905. Sea-shore life: The invertebrates of the New York coast. New York Aquarium Nature Series, No. 1, 181 pp., 119 figs.

McAndrew, Robert.

1860. List of the British marine invertebrate fauna, $71 \mathrm{pp.}$ London.

Mcintosh, William Carmichael.

1901. The coloration of marine animals. Ann. Mag. Nat. Hist., ser. 7, vol. 7 , pp. 221-240.

Miers, Edward J.

1876. Catalogue of the stalk- and sessile-eyed Crustacea of New Zealand, xii +136 pp., 3 pls. London.

1886. Report on the Brachyura: Report on the Scientific Results of the Voyage of H. M. S. Challenger, Zoology, vol. 17, pt. 49, 1+362 pp., 29 pls.

Milne-Edwards, Alphonse.

1862. Faune carcinologique. In Maillard's "Notes sur l'l̂le de la Réunion (Bourbon)," pp. F1-F16, 3 pls. Paris.

1884. L'expédition du Talisman faite dans l'océan Atlantique sous les auspices des ministres de la marine et de l'instruction publique. Bull. Hebdomadaire Assoc. Sci. France, 1884, pp. 1-31.

Milne-Edwards, Alphonse, and Bouvier, Eugène Louis.

1894. Crustacés décapodes provenant des campagnes du yacht l'Hirondelle (1886, 1887, 1888), pt. li Brachyures et anomures. Rés. Camp. Sci. Monaco, fasc. 7, 112 pp., 4 figs., 11 pls. 
1899. Crustacés décapodes provenant des campagnes de l'Hirondelle (supplément) et de la Princesse-Alice (1891-1897). Rés. Camp. Sci. Monaco, fasc. 13, 106 pp., 4 pls.

1900. Crustacés décapodes, pt. 1: Brachyures et anomures. Expéd. Sci. Travailleur et Talisman, 396 pp., 32 pls. Paris.

Milne-Edwards, Henri.

1837. Histoire naturelle des crustacés, vol. 2, $532 \mathrm{pp.} \mathrm{Paris.}$

1852. Observations sur les affinités zoologiques et la classification naturelle des crustacés. Premier mémoire: Remarques sur la manière de charactériser les groupes zoologiques, et sur les principaux types secondaires qui dérivent du type classique de l'animal crustacé. Ann. Sci. Nat., ser. 3, vol. 18, pp. 109-196, 9 pls.

Milne-Edwards, Henri, and Lucas, Hippolyte.

1843. Crustacés. In d'Orbigny's "Voyage dans l'Amérique Méridionale," vol. 6 , pt. 1 , pp. $1-39,19$ pls. Paris.

Miranda y Rivera, Alvaro de.

1921. Algunos crustáceos de la colección del Laboratorio Biológico de Málaga. Bol. Pescas, Madrid, pp. 179-205, 3 figs.

Monod, Théodore.

1927. Contribution à la faune du Cameroun: Crustacea, IV: Decapoda (excl. Palaemonidae, Atyidae et Potamonidae). Faun. Colon. Française, vol. 1, pp. 593-624, 3 figs.

1932. Brachyura maroccana, pt. 2: Dromiidea, Oxystomata, Oxyrhyncha, Brachyrhyncha (excl. Pinnoteridae). Bull. Soc. Sci. Nat. Maroc, vol. 12, Nos. 7-8, pp. 199-220, 7 figs.

1933. Sur quelques crustacés de l'Afrique Occidentale. (Liste des décapodes mauritaniens et des xanthidés ouestafricains.) Bull. Com. Êtud. Hist. Sci. Afr. Occ. Française, vol. 15, Nos. 2-3, 1932, pp. 1-93, 26 figs.

1939. Sur quelques crustacés de la Guadeloupe (Mission P. Allorge, 1936). Bull. Mus. Hist. Nat. Paris, ser. 2, vol. 11, No. 6, pp. 557-568, 11 figs.

Morison, Samuel Eliot.

1942. Admiral of the ocean sea: A life of Christopher Columbus, vol. 1, $\mathrm{xlv}+448 \mathrm{pp}$. Boston.

Moseley, Henry Nottige.

1879. Notes by a naturalist on the Challenger, being an account of various observations made during the voyage of H. M. S. Challenger round the world, xvi+620 pp., figs. London.

MÜLler, Fritz.

1881. Farbenwechsel bei Krabben und Garneelen. Kosmos, Leipzig, vol. 8, fasc. 12 , pp. $472-473$.

MÜller, Otto Frederik.

1776. Zoologiae Danicae Prodromus, seu Animalium Daniae et Norvegiae indigenarum characteres, nominam et synonyma imprimis popularium, xxxii +282 pp. Copenhagen.

Murray, John, and HJort, Johan.

1912. Depths of the ocean, $\mathrm{xx}+821$ pp., 575 figs., 9 pls., 1 map. London.

Nicolet, Hercule.

1849. Crustaceos. In Gay's "Historia Fisica y Politica de Chile," Zool., vol. 3, pp. 115-318. Paris.

Nobili, Giuseppe.

1906. Faune carcinologique de la Mer Rouge: Décapodes et Stomatopodes. Ann. Sci. Nat., Zool., ser. 9, vol. 4, pp. 1-347, 12 figs., 11 pls. 
Nobre, Augusto.

1931. Crustáceos decápodes e stomatópodes marinhos de Portugal, iv +307 pp., 144 figs., 2 pls. Pôrto.

1936. Fauna marinha de Portugal: IV, Crustáceos decápodes e stomatópodes marinhos de Portugal, viii +213 pp., 61 pls. Pôrto.

Norman, Alfred Merle.

1907. Notes on the Crustacea of the Channel Islands. Ann. Mag. Nat. Hist., ser. 7, vol. 20, pp. 356-371, 2 pls.

Norman, Alfred Merle, and Brady, George Stewardson.

1909. The Crustacea of Northumberland and Durham. Trans. Nat. Hist. Soc. Northumberland, Durham, and Newcastle-upon-Tyne, new ser., vol. 3, pt. 2, 168 pp., 2 pls.

Norman, A. M., and Scott, Thomas.

1906. The Crustacea of Devon and Cornwall, $x v+232$ pp., 24 pls. London.

Nutting, Charles Cleveland.

1895. Narrative and preliminary report of Bahama Expedition. Bull. Lab. Nat. Hist. State Univ. Iowa, vol. 3, Nos. 1-2, vii +251 pp., 20 pls.

Olivier, Guillaume Antoine.

1791. Encyclopedie méthodique: Histoire naturelle: Insectes, vol. 6, $704 \mathrm{pp}$. Paris.

Ortmann, Arnold Edward.

1893. Decapoden und schizopoden. Ergebn. Plankton-Exped., vol. 2,120 pp., 1 fig., 10 pls.

1894. Die Decapoden-Krebse des Strassburger Museums. VIII. Theil. Abtheilung: Brachyura (Brachyura genuina Boas). III. Unterabtheilung: Cancroidea, 2. Section: Cancrinea, 2. Gruppe: Catometopa. Zool. Jahrb., Abt. Syst., vol. 7, pp. 683-772, 1 pl.

1899. Gliederfüssler: Arthropoda. In Bronn's “Klassen und ordnungen des Thier-reichs," vol. 5, Abt. 2, Lief. 53-56, pp. 1169-1232. Leipzig.

Osbeck, Peter.

1771. A voyage to China and the East Indies, vol. 2, $152 \mathrm{pp}$. London. [Translated by J. R. Forster.]

Pennant, Thomas.

1777. Crustacea, Mollusca, Testacea. British Zoology, vol. 4, $\mathrm{xx}+154$ pp., 93 pls.

Perkins, Michael.

1928. A simple key to the crabs (Brachyura) of Britain and the north-east Atlantic. Scottish Nat., Mar.-Apr., 1928, pp. 53-59; May-June, 1928, pp. 87-94.

Pesta, Отto.

1912. Die Decapoden-Krebse der Adria in Bestimmungstabellen zusammengestellt. Arch. Naturg., Jahrg. 78, Abt. A, Heft 1, pp. 93-126.

1918. Die Decapodenfauna der Adria. Versuch einer Monographie, $x+500$ pp., 150 figs., 1 chart. Leipzig and Vienna.

Pope, Elizabeth C.

1948. Hitch-hikers of the sea. Australian Mag., vol. 9, No. 9, pp. 293-297.

Pouchet, Georges, and Guerne, Jules de.

1886. Sur l'alimentation des tortues marines. Comptes Rendus Acad.

Sci. Paris, vol. 102 , No. 15 , pp. $877-879$.

Rankin, Walter Mead.

1900. The Crustacea of the Bermuda Islands, with notes on collections made by the New York University Expeditions in 1897 and 1898. Ann.

New York Acad. Sci., vol. 12, No. 12, pp. 521-548, 1 pl. 


\section{Rathbun, Mary Jane.}

1897a. A revision of the nomenclature of the Brachyura. Proc. Biol. Soc. Washington, vol. 11, pp. 153-167.

1897b. List of the decapod Crustacea of Jamaica. Ann. Inst. Jamaica, vol. 1, No. 1, 46 pp.

1898a. The Brachyura of the biological expedition to the Florida Keys and the Bahamas in 1893. Bull. Lab. Nat. Hist. State Univ. Iowa, vol. 4, pp. 250-294, 9 pls.

1898b. The Brachyura collected by the U. S. Fish Commission Steamer Albatross on the voyage from Norfolk, Virginia, to San Francisco, California, 1887-1888. Proc. U. S. Nat. Mus., vol. 21, pp. 567-616, 4 pls.

1900a. The decapod crustaceans of West Africa. Proc. U. S. Nat. Mus., vol. 22 , pp. 271-316, 2 figs.

1900b. Synopsis of North-American invertebrates, XI: The catometopus or grapsoid crabs of North America. Amer. Nat., vol. 34, No. 403. pp. 583-592, 15 figs.

1902. Papers from the Hopkins Stanford Galapagos Expedition, 1898-1899, VIII: Brachyura and Macrura. Proc. Washington Acad. Sci., vol. 4, pp. 275-292, 4 figs., 1 pl.

1904. Decapod crustaceans of the northwest coast of North America. Harriman Alaska Exped., vol. 10, pp. 1-190, 95 figs., 10 pls. ${ }^{3}$

1905. Fauna of New England, 5: List of Crustacea. Occas. Pap. Boston Soc. Nat. Hist., vol. 7, pp. 1-117.

1906. The Brachyura and Macrura of the Hawaiian Islands. Bull. U. S. Fish Comm., 1903, pt. 3, pp. 827-930, i-viii, 79 figs., 24 pls.

1907. Reports on the scientific results of the expedition to the tropical Pacific, in charge of Alexander Agassiz, by the U. S. Fish Commission Steamer Albatross. etc., IX: Reports on the scientific results of the expedition to the eastern tropical Pacific, in charge of Alexander Agassiz, by the U. S. Fish Commission Steamer Albatross, etc. X: The Brachyura. Mem. Mus. Comp. Zool., vol. 35, No. 2, pp. 23-74, 9 pls.

1910. The stalk-eyed Crustacea of Peru and the adjacent coast. Proc. U. S. Nat. Mus., vol. 38, pp. 531-620, 21 pls.

1914. New genera and species of American brachyrhynchous crabs. Proc. U. S. Nat. Mus., vol. 47, pp. 117-129, 5 figs., 10 pls.

1918. The grapsoid crabs of America. U. S. Nat. Mus. Bull. 97, xxii +461 pp., 172 figs., 161 pls.

1924. Brachyuran crabs collected by the Williams Galápagos Expedition, 1923. Zoologica, New York, vol. 5, No. 14, pp. 153-159, 1 fig., 1 pl.

1929. Canadian Atlantic fauna, 10: Arthropoda; 10m: Decapoda, 38 pp., 53 figs. St. Andrews.

1933. Brachyuran crabs of Porto Rico and the Virgin Islands. Sci. Surv. Porto Rico and Virgin Ids., New York Acad. Sci., vol. 15, pt. 1, pp. 1-121, 107 figs.

Richardson, L. R.

1949. A guide to the brachyrhynchous crabs. Tuatara, New Zealand, vol. 2, No. 1, pp. 29-36, 2 pls.

Roux, Polydore.

1828. Crustacés de la Méditerranée et de son littoral, 176 pp., 45 pls. Paris. 


\section{Sakai, Tune.}

1934. Brachyura from the coast of Kyusyu, Japan. Sci. Rep. Tokyo Bunrika Daigaku, sec. B, vol. 1, No. 25, pp. 281-330, 26 figs., 2 pls.

1936. Crabs of Japan, 1935, 239 pp., 122 figs., 66 pls. Tokyo.

1939. Studies on the crabs of Japan, IV: Brachygnatha, Brachyrhyncha, pp. 365-741, 1-23, 129 figs., 70 pls. Tokyo.

Say, Thomas.

1817. An account of the Crustacea of the United States. Journ. Acad. Nat. Sci. Philadelphia, vol. 1, No. 6, pp. 97-102.

1818. Observations on some of the animals described in the account of the Crustacea of the United States. Journ. Acad. Nat. Sci. Philadelphia, vol. 1, pp. 442-444.

Schmitt, Waldo Lasalle.

1921. The marine decapod Crustacea of California. Univ. California Publ. Zool., vol. 23, 470 pp., 165 figs., 50 pls.

Sivertsen, Erling.

1933. The Norwegian Zoological Expedition to the Galapagos Islands 1925, conducted by Alf Wollebaek, VII: Littoral Crustacea Decapoda from the Galápagos Islands. Medd. Zool. Mus. Oslo, No. 38, 23 pp., 4 pls.

Sloane, Hans.

1725. A voyage to the islands of Madera, Barbados, Nieves, St. Christophers, and Jamaica, vol. 2, xviii +499 pp., 125 pls. London.

Smith, Sidney Irving.

1879. The stalk-eyed crustaceans of the Atlantic coast of North America north of Cape Cod. Trans. Connecticut Acad. Arts and Sci., vol. 5 , pt. 1 , pp. $27-136,5$ pls.

1880. Occasional occurrence of tropical and sub-tropical species of decapod Crustacea on the coast of New England. Trans. Connecticut Acad. Arts and Sci., vol. 4, pp. 254-267.

1886. Report on the decapod Crustacea of the Albatross dredgings off the east coast of the United States during the summer and autumn of 1884. Ann. Rep. U. S. Fish Comm., 1885, pp. 605-705, 20 pls.

Smith, S. I., and Harger, Oscar.

1874. Report on the dredgings in the region of St. George's Banks, in 1872. Trans. Connecticut Acad. Arts and Sci., vol. 3, pt. 1, pp. 1-57, 8 pls. Stebbing, Thomas Roscoe Rede.

1893. A history of Crustacea. Recent Malacostraca, xvii+466 pp., 32 figs., 19 pls. New York.

1905. South African Crustacea, part 3: Marine Investigations in South Africa, vol. 4, pp. 21-123, 10 pls.

1910. General catalogue of South African Crustacea. [Pt. 5: of South African Crustacea, for the Marine Investigations in South Africa.] Ann. South African Mus., vol. 6, pt. 4, pp. 281-593, 8 pls.

1914a. Crustacea from the Faulkland Islands collected by Mr. Rupert Vallentin, F. L. S., pt. 2. Proc. Zool. Soc. London, 1914, pp. 341378,9 pls.

1914b. Stalk-eyed Crustacea Malacostraca of the Scottish National Antaretic Expedition. Trans. Roy. Soc. Edinburgh, vol. 50, pt. 2, No. 9, pp. 253-307, $10 \mathrm{pls}$.

Steinbeck, John, and Ricketts, Edward Flanders.

1941. Sea of Cortez, $\mathrm{x}+598$ pp., 40 pls., 2 charts. New York. 
Stimpson, William.

1858. Prodromus descriptionis animalium evertebratorum, quae in Expeditione ad Oceanum Pacificum Septentrionalem, a Republica Federata missa, Cadwaladaro Ringgold et Johanne Rodgers Ducibus, observavit et descripsit, pt. 5: Crustacea Ocypodoidea. Proc. Acad. Nat. Sci. Philadelphia, vol. 10, pp. 93-111 [39-56].

1860. Notes on North American Crustacea, in the Museum of the Smithsonian Institution, No. II: Ann. Lyc. Nat. Hist. New York, vol. 7, pp. 177-246 [49-118], 2 pls.

1907. Report on the Crustacea (Brachyura and Anomura) collected by the North Pacific Exploring Expedition, 1853-1856. Smithsonian Misc. Coll., vol. 49, pp. 1-240, 26 pls.

Stossich, Michele.

1880. Prospetto della fauna del mare Adriatico, pt. 3. Boll. Soc. Adriatica Sci. Nat. Trieste, vol. 6, pp. 178-271.

Sumner, Francis B.; Osburn, Raymond C.; and Cole, Leon J.

1913. A biological survey of the waters of Woods Hole and vicinity, pt. 2, sec. 3: A catalogue of the marine fauna. Bull. U. S. Bur. Fish., vol. 31 , pt. 2 , pp. $547-794$.

Targioni Tozzetti, Adolfo.

1872. Catalogo di crostacei podottalmi brachiuri e anomouri raccolti nel viaggio di circumnavigazione della Fregata italiana Magenta. Atti. Soc. Ital., Milan, vol. 15, pp. 1-12.

1877. Zoologia del viaggio intorno al globo della R. Pirocorvetta Magenta durante gli anni 1865-68. Crostacei brachiuri e anomouri. Pubblicazioni del R. Instituto di Studi Superiori pratici e di Perfezionamento in Firenze, Sezione di Scienze Fisiche e Naturali, vol. 1, xxix +257 pp., 3 figs., 13 pls.

Tesch, Johan Jacob.

1918. The Decapoda Brachyura of the Siboga Expedition, I: Hymenosomidae, Retroplumidae, Ocypodidae, Grapsidae and Gecarcinidae. Siboga-Exped., monogr. 39, 148 pp., 6 pls.

Thompson, D'Arcy Wentworth.

1901. A catalogue of Crustacea and of Pycnogonida contained in the Museum of University College, Dundee, $\mathrm{v}+56 \mathrm{pp}$. Dundee.

Thompson, J. V.

1836. Of the double metamorphosis in Macropodia phalangium, or spidercrab, with proofs of the larvae being zoëa in Gegarcinus hydrodromus, Thelphusa erythropus, Eriphia carribaea, and Grapsus pelagicus. Ent. Mag., vol. 3, art. 33, pp. 370-375, 6 figs.

Urita, Tomoye.

1926. A check list of Brachyura found in Kagoshima Prefecture, Japan, iii +41 pp. Tsingtao.

Verrill, Addison Emory.

1885. Results of the explorations made by the steamer Albatross off the northern coast of the United States, in 1883. Ann. Rep. U. S. Fish. Comm., 1883, pp. 503-699 [1-197], 44 pls.

1908. Decapod Crustacea of Bermuda I: Brachyura and Anomura, their distribution, variations, and habits. Trans. Connecticut Acad. Arts and Sci., vol. 13, pp. 299-474, 68 figs., 20 pls.

Wagner, Moritz.

1880. Über die Entstehung der Arten durch Absonderung, II: Die Mimicry. Kosmos, Leipzig, vol. 7, Heft 2, pp. 89-99. 
Ward, Melbourne.

1939. The Brachyura of the Second Templeton Crocker-American Museum

Expedition to the Pacific Ocean. Amer. Mus. Nov., No. 1049, 15 pp., 17 figs.

Weymouth, Frank Walter.

1910. Synopsis of the true crabs (Brachyura) of Monterey Bay, California. Leland Stanford Junior Univ. Publ., univ. ser., No. 4, 64 pp., 9 figs., $14 \mathrm{pls}$.

White, Adam.

1847. List of the specimens of Crustacea in the collection of the British Museum, viii+143 pp. London.

1850. List of the specimens of British animals in the collection of the British Museum, pt. 4: Crustacea, iv +141 pp. London.

Young Charles G.

1900. The stalk-eyed Crustacea of British Guiana, West Indies, and Bermuda, xix +514 pp., figs., 7 pls. London.

Zariquiey Alvarez, Ricardo.

1946. Crustáceos Decápodos Mediterráneos. Manual para la clasificación de las especies que pueden capturarse en las costas mediterráneas españolas. Inst. Español Estudios Mediterráneos Publ. Biologia Mediterránea, vol. 2, 181 pp., 174 figs., 26 pls. 


\section{$2 \mathrm{BHL}$ Biodiversity Heritage Library}

Chace, Fenner A. 1951. "The oceanic crabs of the genera Planes and Pachygrapsus." Proceedings of the United States National Museum 101(3272), 65-103.

View This Item Online: https://www.biodiversitylibrary.org/item/31795

Permalink: https://www.biodiversitylibrary.org/partpdf/30772

\section{Holding Institution}

Smithsonian Libraries

\section{Sponsored by}

Smithsonian

\section{Copyright \& Reuse}

Copyright Status: NOT_IN_COPYRIGHT

Rights: https://www.biodiversitylibrary.org/permissions/

This document was created from content at the Biodiversity Heritage Library, the world's largest open access digital library for biodiversity literature and archives. Visit BHL at https://www.biodiversitylibrary.org. 